\title{
Article \\ NMR Properties of the Cyanide Anion, a Quasisymmetric Two-Faced Hydrogen Bonding Acceptor
}

\author{
Ilya G. Shenderovich ${ }^{1,2, * \mathbb{D}}$ and Gleb S. Denisov ${ }^{2}$ \\ 1 Institute of Organic Chemistry, University of Regensburg, Universitaetstrasse 31, 93053 Regensburg, Germany \\ 2 Department of Physics, St. Petersburg State University, 198504 St. Petersburg, Russia; gldenisov@yandex.ru \\ * Correspondence: Ilya.Shenderovich@ur.de
}

check for updates

Citation: Shenderovich, I.G.;

Denisov, G.S. NMR Properties of the Cyanide Anion, a Quasisymmetric Two-Faced Hydrogen Bonding Acceptor. Symmetry 2021, 13, 1298. https://doi.org/10.3390/sym13071298

Academic Editor: Aneta Jezierska

Received: 18 June 2021

Accepted: 17 July 2021

Published: 19 July 2021

Publisher's Note: MDPI stays neutral with regard to jurisdictional claims in published maps and institutional affiliations.

Copyright: (c) 2021 by the authors. Licensee MDPI, Basel, Switzerland. This article is an open access article distributed under the terms and conditions of the Creative Commons Attribution (CC BY) license (https:// creativecommons.org/licenses/by/ $4.0 /)$.

\begin{abstract}
The isotopically enriched cyanide anion, $\left({ }^{13} \mathrm{C} \equiv{ }^{15} \mathrm{~N}\right)^{-}$, has a great potential as the NMR probe of non-covalent interactions. However, hydrogen cyanide is highly toxic and can decompose explosively. It is therefore desirable to be able to theoretically estimate any valuable results of certain experiments in advance in order to carry out experimental studies only for the most suitable molecular systems. We report the effect of hydrogen bonding on NMR properties of ${ }^{15} \mathrm{~N} \equiv{ }^{13} \mathrm{CH} \cdots X$ and ${ }^{13} \mathrm{C} \equiv{ }^{15} \mathrm{NH} \cdots X$ hydrogen bonding complexes in solution, where $\mathrm{X}={ }^{19} \mathrm{~F},{ }^{15} \mathrm{~N}$, and $\mathrm{O}={ }^{31} \mathrm{P}$, calculated at the $\omega \mathrm{B} 97 \mathrm{XD} /$ def2tzvp and the polarizable continuum model (PCM) approximations. In many cases, the isotropic ${ }^{13} \mathrm{C}$ and ${ }^{15} \mathrm{~N}$ chemical shieldings of the cyanide anion are not the most informative NMR properties of such complexes. Instead, the anisotropy of these chemical shieldings and the values of scalar coupling constants, including those across hydrogen bonds, can be used to characterize the geometry of such complexes in solids and solutions. ${ }^{1} \mathrm{~J}\left({ }^{15} \mathrm{~N}^{13} \mathrm{C}\right)$ strongly correlates with the length of the $\mathrm{N} \equiv \mathrm{C}$ bond.
\end{abstract}

Keywords: cyanide; hydrogen bonding; non-covalent interactions; NMR; chemical shift anisotropy; scalar coupling; DFT; GIAO

\section{Introduction}

Hydrogen cyanide and cyanide salts are ubiquitous compounds. They can be both the starting ingredients of life [1,2] and the reason for its end [3-5]. The most distinctive feature of the cyanide anion is that its two ends are capable of almost equal non-covalent interactions [6]. As a result, its orientation in crystalline cyanide salts is often disordered [7-11]. The same feature is responsible for the polymerization of hydrogen cyanide, resulting in materials with different characteristics and properties [12-15]. Dimers [16-18] and linear clusters $[19,20]$ of hydrogen cyanide, its crystal structure [21], and its aggregates with the cyanide anion [22] and other proton acceptors [23-26] were studied both experimentally and theoretically. The knowledge gained in these studies was used in practical applications [27-32].

A deeper understanding of the properties of non-covalent interactions involving the cyanide anion in condensed matter systems can be obtained using Nuclear Magnetic Resonance (NMR) spectroscopy. Although it can be done using naturally abundant $\left({ }^{12} \mathrm{C} \equiv{ }^{14} \mathrm{~N}\right)^{-}[33,34],\left({ }^{13} \mathrm{C} \equiv{ }^{14} \mathrm{~N}\right)^{-}[8,35]$, and $\left({ }^{12} \mathrm{C} \equiv{ }^{15} \mathrm{~N}\right)^{-}[36]$, more can be learned with isotopically enriched $\left({ }^{13} \mathrm{C} \equiv{ }^{15} \mathrm{~N}\right)^{-}[37-41]$. It appears that the isotropic ${ }^{13} \mathrm{C}$ and ${ }^{15} \mathrm{~N} N M R$ chemical shifts of the cyanide anion change characteristically when the corresponding atom participates in covalent or non-covalent interactions and can therefore be used to study these interactions $[42,43]$. In this sense, the properties of these isotropic chemical shifts are similar to the ${ }^{15} \mathrm{~N}$ isotropic chemical shift of pyridines [44,45]. However, even for pyridines, non-covalent interactions of different nature can lead to similar changes in the ${ }^{15} \mathrm{~N}$ isotropic chemical shift [46]. Direct covalent or non-covalent interactions are not the only factors that can have a measurable effect on the isotropic chemical shift. The vibrational wave function of the molecule [47-49], solvent effects [50,51], molecular exchange [52], and the 
crystal field [53] are important as well. All of these factors are particularly important for the cyanide anion, which has two similar active centers for non-covalent interactions. However, it is this feature that can be used to solve the problem.

Isotropic chemical shifts are not the only NMR parameters that can be useful. In solution, the structure of hydrogen bonded complexes can be elucidated using scalar spin-spin couplings including those across hydrogen bonds [54-59]. For ${ }^{12} \mathrm{C} \equiv{ }^{15} \mathrm{~N}-\mathrm{H} \cdots{ }^{19} \mathrm{~F}$ dissolved in a $\mathrm{CDF}_{3} / \mathrm{CDF}_{2} \mathrm{Cl}$ mixture, three scalar couplings were measured experimentally at $130 \mathrm{~K}$ : $\left|{ }^{1} \mathrm{~J}\left({ }^{15} \mathrm{~N}^{1} \mathrm{H}\right)\right|=92 \mathrm{~Hz},\left|{ }^{2 \mathrm{~h}} \mathrm{~J}\left({ }^{15} \mathrm{~N}^{19} \mathrm{~F}\right)\right|=61 \mathrm{~Hz}$, and $\left|{ }^{1 \mathrm{~h}} \mathrm{~J}\left({ }^{1} \mathrm{H}^{19} \mathrm{~F}\right)\right|=63 \mathrm{~Hz}$ [60]. Even when some couplings are not available or averaged to zero by rapid molecular exchange, the ${ }^{1} \mathrm{~J}\left({ }^{13} \mathrm{C}^{15} \mathrm{~N}\right)$ coupling can still provide important information about the qualitative structure of such complexes. In solids, the anisotropy of the chemical shielding is much more sensitive to external influences $[61,62]$ and molecular dynamics $[63,64]$ than the isotropic value. Consequently, $\left({ }^{13} \mathrm{C} \equiv{ }^{15} \mathrm{~N}\right)^{-}$is an ideal hydrogen bond acceptor for NMR studies both in solutions and in solids, because several independent parameters can be measured for the same sample under the same experimental conditions. However, hydrogen cyanide is highly toxic and can decompose explosively. It is therefore desirable to theoretically estimate any valuable results of certain experiments in advance and to carry out experimental studies only for the most suitable molecular systems.

In this work we report on a computational study of a variety of ${ }^{15} \mathrm{~N} \equiv{ }^{13} \mathrm{C}-\mathrm{H} \cdots \mathrm{X}$ and ${ }^{13} \mathrm{C} \equiv{ }^{15} \mathrm{~N}-\mathrm{H} \cdots \mathrm{X}$ hydrogen bonded complexes, where $\mathrm{X}={ }^{19} \mathrm{~F}-\mathrm{R},{ }^{15} \mathrm{~N}-\mathrm{R}, \mathrm{O}={ }^{31} \mathrm{P}-\mathrm{R}$ and cover a wide range of basicity. $\left(\mathrm{Li}^{15} \mathrm{~N}^{13} \mathrm{C}\right)_{4} \cdots\left({ }^{1} \mathrm{H}_{4}{ }^{15} \mathrm{~N}\right)^{+}$and $\left(\mathrm{Li}^{13} \mathrm{C}^{15} \mathrm{~N}\right)_{4} \cdots\left({ }^{1} \mathrm{H}_{4}{ }^{15} \mathrm{~N}\right)^{+}$hydrogen bonded aggregates have been used to study the effect of competing non-covalent interactions. The objective of this study was to explore the dependence of NMR parameters on the properties of hydrogen bonding. For each of these parameters, we assessed the amplitude of possible changes and the ability to use these changes to differentiate between different interactions.

\section{Materials and Methods}

Gaussian 09.D.01 program package was used [65]. Geometry optimizations were done in the $\omega B 97 X D /$ def2tzvp approximation $[66,67]$. The identity of minima was confirmed by the absence of imaginary vibrational frequencies. NMR parameters were calculated using the Gauge-Independent Atomic Orbital GIAO method [68] in the $\omega$ B97XD/pcJ-2 approximation $[69,70]$. All calculations were done using the Polarizable Continuum Model (PCM) with water as a solvent [71-73], unless otherwise noted. The default SCRF=PCM method was used to construct the solute cavity.

The $\omega$ B97XD functional and the pcJ-2 basis set are capable of correctly reproducing the experimental values of the chemical shielding and scalar spin-spin coupling $[50,53,74]$. On the contrary, both the PCM and the solvation model based on density (SMD) approximation [75] underestimate solvent effects on the geometry of hydrogen bonded complexes [51,76]. The resulting deviations can only be neglected in specific cases [77-79]. For polar solvents, a change in the values of the dielectric constant has a negligible effect. There are a number of approaches that can be used to properly simulate solvent effects [80-85]. None of these approaches are universal and effortlessly applicable to an arbitrary molecular system. Consequently, the geometries of the molecular complexes used below do not correspond to either the averaged or the most expected experimental geometries in a polar medium. These geometries are used only for a qualitative assessment of the NMR parameters that can be expected in solution for such complexes.

Chemical shieldings are tensor quantities. For the cyanide anion, the principal components of the ${ }^{13} \mathrm{C}$ and ${ }^{15} \mathrm{~N}$ shielding tensors, $\sigma_{11} \leq \sigma_{22} \leq \sigma_{33}$, can be easily represented in the molecular coordinate system. One of these components is parallel to the $\mathrm{C} \equiv \mathrm{N}$ bond and the other two are normal to this bond and are equal. In this paper the isotropic value of these shielding tensors, $\sigma_{\text {iso }}=\left(\sigma_{11}+\sigma_{22}+\sigma_{33}\right) / 3$, and their span, $\Omega=\sigma_{33}-\sigma_{11}$, will be discussed. More detailed description can be found elsewhere [86-88]. 


\section{Results and Discussion}

Figure 1 shows the structures of $\mathrm{NCH}$ and $\mathrm{CNH}$ complexes with various proton acceptors and their relative energies. For most of these complexes, the $\mathrm{NCH} \cdots \mathrm{X}$ form is energetically more preferable than the $\mathrm{CNH}$...X form. The opposite situation is observed for complexes with pyridine-4-amine and 1-azabicyclo[2.2.2]octane, Figure 1e,f. This result is associated with the fact that the energy of hydrogen cyanide is $65 \mathrm{~kJ} / \mathrm{mol}$ lower than the energy of hydrogen isocyanide, Figure 1a. This difference is much smaller in their complexes with proton acceptors. Consequently, one can say that the binding energy of the $\mathrm{CNH} \cdots \mathrm{X}$ form is much higher [89], and this form may be stable if the carbon atom participates in another covalent or non-covalent interaction [43,90-92]. The analysis of the energetically most favorable structures with the hydrogen bonded cyanide anion at different conditions is beyond the scope of this study. The NMR parameters of both forms are reported below.

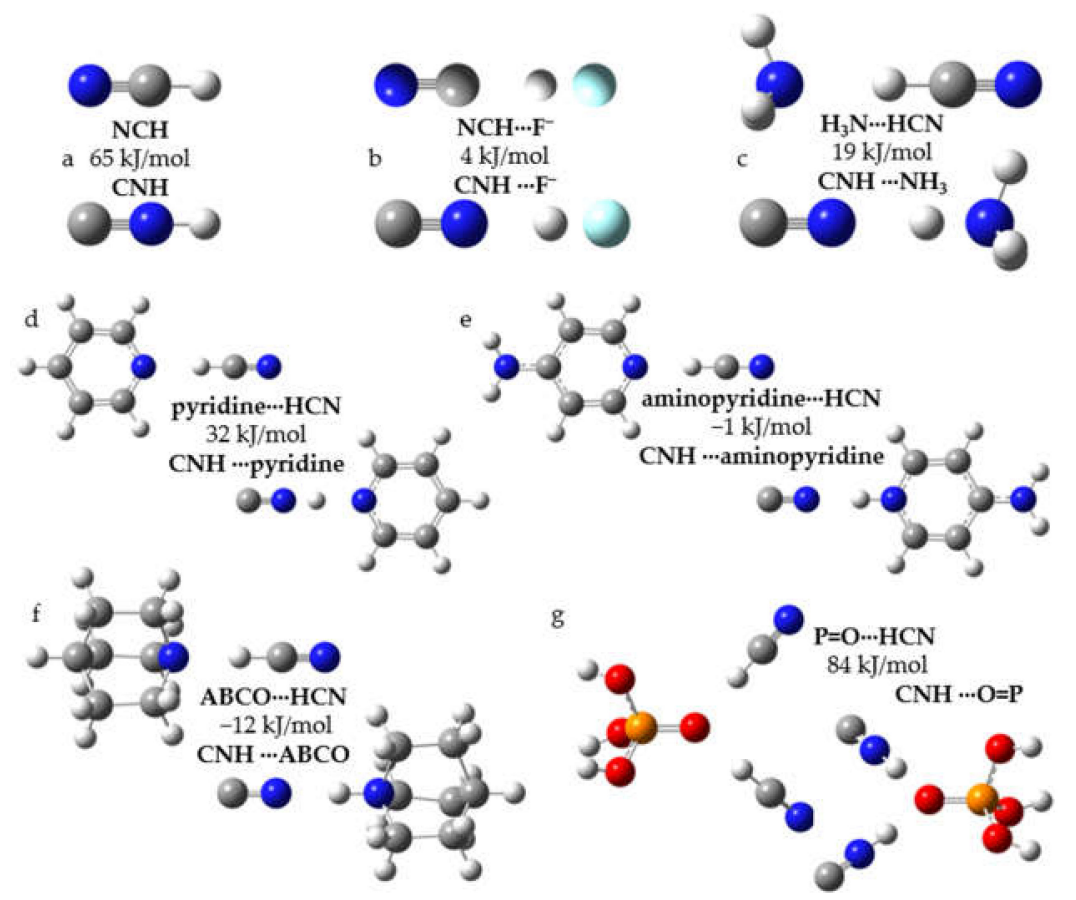

Figure 1. The structure of $\mathrm{NCH}$ and $\mathrm{CNH}$ complexes with proton acceptors and their relative energies $\Delta \mathrm{E}=\mathrm{E}(\mathrm{CNH}$-form $)-\mathrm{E}(\mathrm{NCH}$-form $)$ obtained at the $\omega \mathrm{B} 97 \mathrm{XD} /$ def2tzvp and $\mathrm{PCM}=$ water approximations. (a) No acceptor, (b) fluoride anion $\left(\mathrm{F}^{-}\right),(\mathbf{c})$ ammonia $\left(\mathrm{NH}_{3}\right),(\mathbf{d})$ pyridine, (e) pyridine-4-amine $(4 \mathrm{AP}),(\mathbf{f})$ 1-azabicyclo[2.2.2] octane $(\mathrm{ABCO}),(\mathrm{g})$ phosphoric acid $(\mathrm{P}=\mathrm{O})$.

\subsection{The Effect of Hydrogen Bonding on the NMR Parameters of NCH and CNH}

The length of the $\mathrm{N} \equiv \mathrm{C}$ bond decreases in the series $(\mathrm{N} \equiv \mathrm{C})^{-}, \mathrm{C} \equiv \mathrm{NH}, \mathrm{N} \equiv \mathrm{CH}$, Table 1 . However, the NMR parameters of these species are mainly determined by the location of the proton, and not by this contraction. Any of these parameters can be used to distinguish between $\mathrm{CNH}$ and $\mathrm{NCH}$. On the contrary, the difference with $(\mathrm{NC})^{-}$, is large only for the atom carrying the proton. The only exception is ${ }^{1} \mathrm{~J}\left({ }^{15} \mathrm{~N}^{13} \mathrm{C}\right)$. The absolute value of this coupling decreases almost linearly with increasing $\mathrm{N} \equiv \mathrm{C}$ distance. The difference of $\sigma_{\text {iso }}\left({ }^{15} \mathrm{~N}\right)$ in $(\mathrm{NC}){ }^{-}$and $\mathrm{CNH}$ is similar to that in pyridine and pyridinium $[44] .{ }^{1} \mathrm{~J}\left({ }^{15} \mathrm{~N}^{1} \mathrm{H}\right)$ in $\mathrm{CNH}$ is the same as in pyridinium [93]. ${ }^{2} \mathrm{~J}\left({ }^{15} \mathrm{~N}^{1} \mathrm{H}\right)$ and ${ }^{2} \mathrm{~J}\left({ }^{13} \mathrm{C}^{1} \mathrm{H}\right)$ in $\mathrm{NCH}$ and $\mathrm{CNH}$ can be measured in the absence of proton exchange. 
Table 1. The $\mathrm{N} \equiv \mathrm{C}$ distances, the isotropic chemical shielding, $\sigma_{\text {iso }}$, the span, $\Omega$, of the shielding tensors of the ${ }^{15} \mathrm{~N}$ and ${ }^{13} \mathrm{C}$ nuclei, and scalar coupling constants of $\mathrm{NC}^{-}, \mathrm{NCH}$, and $\mathrm{CNH}$ obtained at the $\mathrm{PCM}=$ water approximation.

\begin{tabular}{|c|c|c|c|c|c|c|c|c|}
\hline \multirow{2}{*}{ Compound } & \multirow{2}{*}{$\mathbf{N} \equiv \mathbf{C}, \AA$} & \multicolumn{2}{|c|}{${ }^{15} \mathrm{~N}$, ppm } & \multicolumn{2}{|c|}{${ }^{13} \mathrm{C}, \mathrm{ppm}$} & \multirow{2}{*}{$\begin{array}{c}{ }^{1} \mathrm{~J}\left({ }^{15} \mathrm{~N}^{13} \mathrm{C}\right) \\
\mathrm{Hz}\end{array}$} & \multirow{2}{*}{$\begin{array}{c}\mathrm{J}\left({ }^{15} \mathrm{~N}^{1} \mathrm{H}\right) \\
\mathrm{Hz}\end{array}$} & \multirow{2}{*}{$\begin{array}{c}\mathrm{J}\left({ }^{13} \mathrm{C}^{1} \mathrm{H}\right) \\
\mathrm{Hz}\end{array}$} \\
\hline & & $\sigma_{\text {iso }}$ & $\Omega$ & $\sigma_{\text {iso }}$ & $\Omega$ & & & \\
\hline${ }^{15} \mathrm{~N} \equiv{ }^{13} \mathrm{C}^{-}$ & 1.1664 & -46 & 585 & 10 & 403 & -7 & - & - \\
\hline${ }^{15} \mathrm{~N} \equiv{ }^{13} \mathrm{C}^{1} \mathrm{H}$ & 1.1436 & -24 & 548 & 65 & 302 & -25 & -11 & 267 \\
\hline${ }^{13} \mathrm{C} \equiv{ }^{15} \mathrm{~N}^{1} \mathrm{H}$ & 1.1585 & 78 & 401 & 13 & 392 & -14 & -121 & 23 \\
\hline
\end{tabular}

$\mathrm{NCH}$ is a weak proton donor. The proton transfer only takes place in its complex with $\mathrm{F}^{-}$anion, $(\mathrm{NC})^{-} \cdots \mathrm{H}-\mathrm{F}$, Table 2 . The $\mathrm{N} \equiv \mathrm{C}$ distance in this complex is shorter than that in free $(\mathrm{NC})^{-}$, but greater than that in $\mathrm{CNH}$. All other complexes have the $\mathrm{NC}-\mathrm{H} \cdots \mathrm{X}$ structure with the $\mathrm{N} \equiv \mathrm{C}$ distance greater than that in free $\mathrm{NCH}$, but shorter than that in free $\mathrm{CNH}$. For the weakest proton acceptor studied here, the $\mathrm{O}=\mathrm{P}$ group, the $\mathrm{N} \equiv \mathrm{C}$ distances in $(\mathrm{NC}-\mathrm{H})_{2} \cdots \mathrm{O}=\mathrm{P}$, and free $\mathrm{NCH}$ are very similar. Note, that in this work we use the $(\mathrm{NC}-\mathrm{H})_{2} \cdots \mathrm{O}=\mathrm{P}$ complex, Figure $1 \mathrm{~g}$. The $\mathrm{O}=\mathrm{P}$ group tends to form two hydrogen bonds at the same time [94-96]. Moreover, the presence of the second bond does not affect the strength of the first one. $\mathrm{CNH}$ is a strong proton donor. The structure $\mathrm{CN}-\mathrm{H} \cdots \mathrm{X}$ is present only for pyridine and the $\mathrm{P}=\mathrm{O}$ group. In these $\mathrm{CN}-\mathrm{H} \cdots \mathrm{X}$ complexes the $\mathrm{N} \equiv \mathrm{C}$ distance is very similar to that in (NC) ${ }^{-} \ldots \mathrm{H}-\mathrm{F}$, Table 2 . It is noteworthy that, for the same proton acceptor, the $\mathrm{H} \cdots \mathrm{X}$ distance in $\mathrm{CN}-\mathrm{H} \cdots \mathrm{X}$ is shorter than in $\mathrm{NC}-\mathrm{H} \cdots \mathrm{X}$.

Table 2. Geometry of $\mathrm{NCH} \cdots \mathrm{X}$ and $\mathrm{CNH} \cdots \mathrm{X}$ complexes obtained at $\mathrm{PCM}=$ water.

\begin{tabular}{ccccccc}
\hline Base $(\mathbf{X})$ & $\mathbf{N} \equiv \mathbf{C}, \mathbf{\AA}$ & $\begin{array}{c}\mathbf{N C H} \cdots \mathbf{X} \\
\mathbf{C} \cdots \mathbf{H}, \mathbf{\mathbf { A }}\end{array}$ & $\mathbf{H} \cdots \mathbf{X} \mathbf{}^{\mathbf{1}} \AA$ & $\mathbf{C} \equiv \mathbf{N}, \AA$ & $\mathbf{C N H} \cdots \mathbf{X}$ & \\
& 1.1599 & 1.5754 & 1.0093 & 1.1636 & 1.5202 & 0.9875 \\
$\mathrm{~F}^{-}$ & 1.1461 & 1.1072 & 1.9093 & 1.1646 & 1.6310 & 1.0790 \\
$\mathrm{H}_{3} \mathrm{~N}$ & 1.1458 & 1.1034 & 1.9051 & 1.1594 & 1.0886 & 1.5705 \\
pyridine & 1.1463 & 1.1109 & 1.8543 & 1.1650 & 1.7032 & 1.0515 \\
$4 \mathrm{AP}$ & 1.1471 & 1.1282 & 1.7753 & 1.1650 & 1.6868 & 1.0578 \\
$\mathrm{ABCO}$ & 1.1448 & 1.087 & 1.90 & 1.1583 & 1.029 & 1.70 \\
$\mathrm{P}=\mathrm{O}$ &
\end{tabular}

${ }^{1}$ The distance between the $\mathrm{NCH}$ or $\mathrm{CNH}$ proton and the proton accepting atom of the base.

$\sigma_{\text {iso }}\left({ }^{15} \mathrm{~N}\right)$ and $\Omega\left({ }^{15} \mathrm{~N}\right)$ can be used to distinguish between different $\mathrm{CN}-\mathrm{H} \cdots \mathrm{X}$ complexes, Table 3. On the contrary, these parameters are very similar in all $(\mathrm{CN})^{-} \ldots \mathrm{H}-\mathrm{X}$ and NC-H $\cdots$ X complexes. $\sigma_{\text {iso }}\left({ }^{13} \mathrm{C}\right)$ and $\Omega\left({ }^{13} \mathrm{C}\right)$ are very similar for all $\mathrm{NC}-\mathrm{H} \cdots \mathrm{X}$ complexes. However, these parameters can be used to distinguish between the $\mathrm{NC}-\mathrm{H} \cdots \mathrm{X},(\mathrm{NC})^{-} \cdots \mathrm{H}-\mathrm{X}$, and $\mathrm{CNHX}$ complexes.

Table 3. The isotropic chemical shielding, $\sigma_{\text {iso }}$, and the span, $\Omega$, of the shielding tensors of the ${ }^{15} \mathrm{~N}$ and ${ }^{13} \mathrm{C}$ nuclei of $\mathrm{NCH} \cdots \mathrm{X}$ and $\mathrm{CNH} \cdots \mathrm{X}$ complexes obtained at $\mathrm{PCM}=$ water.

\begin{tabular}{ccccccccc}
\hline & \multicolumn{4}{c}{$\mathbf{N C H} \cdots \mathbf{X}$} & \multicolumn{4}{c}{$\mathbf{C N H} \cdots \mathbf{X}$} \\
Base (X) & \multicolumn{1}{c}{${ }^{\mathbf{1 5}} \mathbf{N}, \mathbf{p} \mathbf{p m}$} & \multicolumn{2}{c}{${ }^{\mathbf{1 3}} \mathbf{C}, \mathbf{p p m}$} & \multicolumn{2}{c}{${ }^{\mathbf{1 5}} \mathbf{N}, \mathbf{p p m}$} & ${ }^{13} \mathbf{C}, \mathbf{p p m}$ \\
& $\boldsymbol{\sigma}_{\text {iso }}$ & $\boldsymbol{\Omega}$ & $\boldsymbol{\sigma}_{\text {iso }}$ & $\boldsymbol{\Omega}$ & $\boldsymbol{\sigma}_{\text {iso }}$ & $\boldsymbol{\Omega}$ & $\boldsymbol{\sigma}_{\text {iso }}$ & $\boldsymbol{\Omega}$ \\
\hline $\mathrm{F}^{-}$ & -33 & 566 & 25 & 383 & -17 & 546 & 14 & 397 \\
$\mathrm{H}_{3} \mathrm{~N}$ & -17 & 538 & 57 & 335 & -27 & 560 & 13 & 398 \\
pyridine & -20 & 560 & 57 & 334 & 39 & 461 & 17 & 388 \\
$4 \mathrm{AP}$ & -19 & 541 & 56 & 336 & -28 & 561 & 11 & 401 \\
$\mathrm{ABCO}$ & -21 & 546 & 55 & 341 & -24 & 559 & 11 & 403 \\
$\mathrm{P}=\mathrm{O}$ & -20 & 544 & 60 & 331 & 59 & 434 & 17 & 389 \\
\hline
\end{tabular}

The geometry of NC-H $\cdots \mathrm{X}$ and $(\mathrm{NC})^{-} \cdots \mathrm{H}-\mathrm{X}$ complexes can be quantitatively characterized using ${ }^{1} \mathrm{~J}\left({ }^{13} \mathrm{C}^{1} \mathrm{H}\right)$, Table 4 . The long range ${ }^{\mathrm{h}} \mathrm{J}\left({ }^{13} \mathrm{CX}\right)$ couplings across the hydrogen bond are also large enough to be observed experimentally. The location of the mobile proton in these complexes can be proved using any scalar coupling. This is trivial for 
${ }^{1} \mathrm{~J}\left({ }^{13} \mathrm{C}^{1} \mathrm{H}\right)$ and ${ }^{\mathrm{h}} \mathrm{J}\left({ }^{1} \mathrm{HX}\right)$. However, because the $\mathrm{N} \equiv \mathrm{C}$ distances in $\mathrm{NC}-\mathrm{H} \cdots \mathrm{X}$ are shorter than in $(\mathrm{NC})^{-} \cdots \mathrm{H}-\mathrm{X},{ }^{1} \mathrm{~J}\left({ }^{15} \mathrm{~N}^{13} \mathrm{C}\right) \geq 20 \mathrm{~Hz}$ in $\mathrm{NC}-\mathrm{H} \cdots \mathrm{X}$ and about $10 \mathrm{~Hz}$ in $(\mathrm{NC})^{-} \cdots \mathrm{H}-\mathrm{X}$. ${ }^{2} \mathrm{~J}\left({ }^{15} \mathrm{~N}^{1} \mathrm{H}\right)$ can be measured in NC-H$\cdots \mathrm{X}$ but not in $(\mathrm{NC})^{-} \cdots \mathrm{H}-\mathrm{X}$. Surprisingly, ${ }^{3 \mathrm{~h}} \mathrm{~J}\left({ }^{15} \mathrm{~N}^{19} \mathrm{~F}\right)$ in $(\mathrm{NC})^{-} \ldots \mathrm{H}-\mathrm{F}$ is large.

Table 4. Scalar coupling constants in $\mathrm{NCH} \cdots$ X obtained at $\mathrm{PCM}=$ water.

\begin{tabular}{|c|c|c|c|c|c|c|}
\hline Base (X) & $\begin{array}{c}{ }^{1} \mathrm{~J}\left({ }^{15} \mathrm{~N}^{13} \mathrm{C}\right) \\
\mathrm{Hz}\end{array}$ & $\begin{array}{c}{ }^{2} \mathrm{~J}\left({ }^{15} \mathrm{~N}^{1} \mathrm{H}\right) \\
\mathrm{Hz}\end{array}$ & $\begin{array}{c}{ }^{1} \mathrm{~J}\left({ }^{13} \mathrm{C}^{1} \mathrm{H}\right) \\
\mathrm{Hz}\end{array}$ & $\begin{array}{c}{ }^{1 \mathrm{~h}} \mathrm{~J}\left({ }^{1} \mathrm{HX}\right) \\
\mathrm{Hz}\end{array}$ & $\begin{array}{c}{ }^{2 \mathrm{~h}} \mathrm{~J}\left({ }^{13} \mathrm{CX}\right) \\
\mathrm{Hz}\end{array}$ & $\begin{array}{c}{ }^{3 h} \mathrm{~J}\left({ }^{15} \mathrm{NX}\right) \\
\mathrm{Hz}\end{array}$ \\
\hline $\mathrm{F}^{-}$ & -10 & -2 & 31 & $291^{1}$ & $314^{1}$ & $-22^{1}$ \\
\hline $\mathrm{H}_{3} \mathrm{~N}$ & -22 & -12 & 258 & $4^{2}$ & $20^{2}$ & $1^{2}$ \\
\hline pyridine & -22 & -12 & 259 & $4^{2}$ & $-21^{2}$ & $1^{2}$ \\
\hline $4 \mathrm{AP}$ & -22 & -12 & 255 & $4^{2}$ & $-24^{2}$ & $1^{2}$ \\
\hline $\mathrm{ABCO}$ & -20 & -12 & 243 & $2^{2}$ & $-23^{2}$ & $1^{2}$ \\
\hline $\mathrm{P}=\mathrm{O}$ & -24 & -12 & 266 & $-2^{3}$ & $7^{3}$ & $0^{3}$ \\
\hline
\end{tabular}

${ }^{1} \mathrm{X}={ }^{19} \mathrm{~F} \cdot{ }^{2} \mathrm{X}={ }^{15} \mathrm{~N} .{ }^{3} \mathrm{X}={ }^{31} \mathrm{P}$

A combination of ${ }^{1} \mathrm{~J}\left({ }^{15} \mathrm{~N}^{1} \mathrm{H}\right)$, and ${ }^{1 \mathrm{~h}} \mathrm{~J}\left({ }^{1} \mathrm{HX}\right)$ can be used to quantitatively characterize the geometry of $\mathrm{CN}-\mathrm{H} \cdots \mathrm{X}$ and $(\mathrm{CN})^{-} \cdots \mathrm{H}-\mathrm{X}$ complexes, Table 5 . The long range ${ }^{\mathrm{h}} \mathrm{J}\left({ }^{15} \mathrm{NX}\right)$ across the hydrogen bond are large, except ${ }^{3 \mathrm{~h}} \mathrm{~J}\left({ }^{15} \mathrm{~N}^{31} \mathrm{P}\right) .{ }^{2} \mathrm{~J}\left({ }^{13} \mathrm{C}^{1} \mathrm{H}\right)$ can be measured in $\mathrm{CN}$ $\mathrm{H} \cdots \mathrm{X}$ only. ${ }^{1} \mathrm{~J}\left({ }^{15} \mathrm{~N}^{13} \mathrm{C}\right)<10 \mathrm{~Hz}$ is characteristic for $(\mathrm{CN})^{-} \cdots \mathrm{H}-\mathrm{X}$. In $\mathrm{CN}-\mathrm{H} \cdots \mathrm{X}$ the value of this coupling is similar to that in (NC) ${ }^{-} \cdots \mathrm{H}-\mathrm{X} \cdot{ }^{3 \mathrm{~h}} \mathrm{~J}\left({ }^{13} \mathrm{C}^{19} \mathrm{~F}\right)$ in $(\mathrm{CN})^{-} \cdots \mathrm{H}-\mathrm{F}$ is large enough to be observed experimentally.

Table 5. Scalar coupling constants in $\mathrm{CNH} \cdots \mathrm{X}$ obtained at $\mathrm{PCM}=$ water.

\begin{tabular}{|c|c|c|c|c|c|c|}
\hline Base (X) & $\begin{array}{c}{ }^{1} \mathrm{~J}\left({ }^{15} \mathrm{~N}^{13} \mathrm{C}\right) \\
\mathrm{Hz}\end{array}$ & $\begin{array}{c}{ }^{1} \mathrm{~J}\left({ }^{15} \mathrm{~N}^{1} \mathrm{H}\right) \\
\mathrm{Hz}\end{array}$ & $\begin{array}{c}{ }^{2} \mathrm{~J}\left({ }^{13} \mathrm{C}^{1} \mathrm{H}\right) \\
\mathrm{Hz}\end{array}$ & $\begin{array}{c}{ }^{1 \mathrm{~h}} \mathrm{~J}\left({ }^{1} \mathrm{HX}\right), \\
\mathrm{Hz}\end{array}$ & $\begin{array}{c}{ }^{3 \mathrm{~h}} \mathrm{~J}\left({ }^{13} \mathrm{CX}\right) \\
\mathrm{Hz}\end{array}$ & $\begin{array}{c}{ }^{2 \mathrm{~h}} \mathrm{~J}\left({ }^{15} \mathrm{NX}\right), \\
\mathrm{Hz}\end{array}$ \\
\hline $\mathrm{F}^{-}$ & -8 & -5 & 3 & $371^{1}$ & $27^{1}$ & $-93^{1}$ \\
\hline $\mathrm{H}_{3} \mathrm{~N}$ & -7 & 1 & 1 & $-66^{2}$ & $-2^{2}$ & $12^{2}$ \\
\hline pyridine & -13 & -94 & 22 & $-5^{2}$ & $-3^{2}$ & $16^{2}$ \\
\hline 4AP & -8 & 3 & 1 & $-97^{2}$ & $-2^{2}$ & $11^{2}$ \\
\hline $\mathrm{ABCO}$ & -8 & 4 & 1 & $-73^{2}$ & $-2^{2}$ & $9^{2}$ \\
\hline $\mathrm{P}=\mathrm{O}$ & -15 & -114 & 25 & $-2^{3}$ & $0^{3}$ & $-3^{3}$ \\
\hline
\end{tabular}

${ }^{1} \mathrm{X}={ }^{19} \mathrm{~F} \cdot{ }^{2} \mathrm{X}={ }^{15} \mathrm{~N} \cdot{ }^{3} \mathrm{X}={ }^{31} \mathrm{P}$.

It is worth taking a closer look at the complex of the cyanide anion with hydrogen fluoride. It is obvious that the fluoride anion in solution interacts not only with hydrogen cyanide but also with a cation. The later interaction is simulated here using lithium fluoride. For hydrogen cyanide the structure of this complex is $\mathrm{NCH} \cdots \mathrm{FLi}$ both at the gas phase and PCM approximations, Table 6. For hydrogen isocyanide the structure of this complex is $\mathrm{CNH} \cdots \mathrm{FLi}$ at the gas phase approximation and $(\mathrm{CN})^{-} \ldots(\mathrm{H}-\mathrm{FLi})^{+}$at the PCM approximation. At the gas phase approximation, the $\mathrm{H} \cdots \mathrm{F}$ distance in $\mathrm{CN}-\mathrm{H} \cdots \mathrm{FLi}$ is much

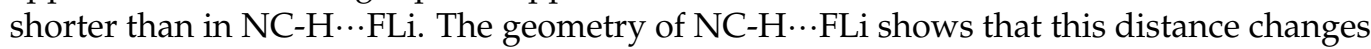
much more than other distances when the influence of the solvent is considered.

Table 6. Geometry of $\mathrm{NCH} \cdots \mathrm{FLi}$ and $\mathrm{CNH} \cdots \mathrm{FLi}$ hydrogen-bonded complexes obtained at the gas phase and $\mathrm{PCM}=$ water approximations.

\begin{tabular}{ccccccc}
\hline \multirow{2}{*}{$\mathbf{P C M}$} & $\mathbf{N} \equiv \mathbf{C}, \AA$ & $\begin{array}{c}\mathbf{N C H} \cdots \mathbf{F L i} \\
\mathbf{C} \cdots \mathbf{H}, \AA\end{array}$ & $\mathbf{H} \cdots \mathbf{F}, \AA$ & $\mathbf{C} \equiv \mathbf{N}, \AA$ & $\mathbf{C N H} \cdots \mathbf{F L i}$ \\
\hline gas & 1.1460 & 1.0980 & 1.6935 & 1.1602 & 1.0438 & 1.5239 \\
water & 1.1484 & 1.1461 & 1.4666 & 1.1605 & 1.2079 & 1.1738 \\
\hline
\end{tabular}

The geometric changes cause changes of the chemical shieldings, Table 7. However, these relationships are anything but self-evident. For $\mathrm{NC}-\mathrm{H} \cdots \mathrm{FLi}$, the use of the PCM approximation leads to large changes in $\sigma_{\text {iso }}\left({ }^{15} \mathrm{~N}\right)$ and $\Omega\left({ }^{15} \mathrm{~N}\right)$, although the $\mathrm{N} \equiv \mathrm{C}$ distance 
changes only slightly. $\mathrm{CN}-\mathrm{H} \cdots \mathrm{FLi}$ and $(\mathrm{CN})^{-} \cdots(\mathrm{H}-\mathrm{FLi})^{+}$have similar $\sigma_{\text {iso }}\left({ }^{13} \mathrm{C}\right)$ and very different $\Omega\left({ }^{13} \mathrm{C}\right)$. The ambiguity of these changes suggests that correctly interpreting the geometry of hydrogen bonded complexes based on NMR data may require comparing several NMR parameters.

Table 7. The isotropic chemical shielding, $\sigma_{\text {iso }}$, and the span, $\Omega$, of the shielding tensors of the ${ }^{15} \mathrm{~N}$ and ${ }^{13} \mathrm{C}$ nuclei of $\mathrm{NCH} \cdots \mathrm{FLi}$ and $\mathrm{CNH} \cdots \mathrm{FLi}$ complexes obtained at the gas phase and $\mathrm{PCM}=$ water approximations.

\begin{tabular}{|c|c|c|c|c|c|c|c|c|}
\hline \multirow{3}{*}{ PCM } & \multicolumn{4}{|c|}{$\mathrm{NCH} \cdots \mathbf{F L i}$} & \multicolumn{4}{|c|}{$\mathrm{CNH} \cdots \mathrm{FLi}$} \\
\hline & \multicolumn{2}{|c|}{${ }^{15} \mathrm{~N}, \mathrm{ppm}$} & \multicolumn{2}{|c|}{${ }^{13} \mathrm{C}, \mathrm{ppm}$} & \multicolumn{2}{|c|}{${ }^{15} \mathrm{~N}, \mathrm{ppm}$} & \multicolumn{2}{|c|}{${ }^{13} \mathrm{C}, \mathrm{ppm}$} \\
\hline & $\sigma_{\text {iso }}$ & $\Omega$ & $\sigma_{\text {iso }}$ & $\Omega$ & $\sigma_{\text {iso }}$ & $\Omega$ & $\sigma_{\text {iso }}$ & $\Omega$ \\
\hline gas & -32 & 561 & 61 & 330 & 57 & 436 & 12 & 395 \\
\hline water & -16 & 538 & 52 & 344 & 16 & 497 & 18 & 361 \\
\hline
\end{tabular}

In contrast, the values of scalar couplings seem to be only marginally dependent on the use of the PCM approximation, Table 8. For NC-H...FLi the main changes, as expected, are observed for ${ }^{1} \mathrm{~J}\left({ }^{13} \mathrm{C}^{1} \mathrm{H}\right),{ }^{1 \mathrm{~h}} \mathrm{~J}\left({ }^{1} \mathrm{H}^{19} \mathrm{~F}\right)$, and ${ }^{2 \mathrm{~h}} \mathrm{~J}\left({ }^{13} \mathrm{C}^{19} \mathrm{~F}\right)$. The change of $\mathrm{CN}-\mathrm{H} \cdots \mathrm{FLi}$ to $(\mathrm{CN})^{-} \cdots(\mathrm{H}-\mathrm{FLi})^{+}$leads to strong changes in ${ }^{1} \mathrm{~J}\left({ }^{15} \mathrm{~N}^{1} \mathrm{H}\right),{ }^{1} \mathrm{~h}\left({ }^{1} \mathrm{H}^{19} \mathrm{~F}\right)$, and ${ }^{2 \mathrm{~h}} \mathrm{~J}\left({ }^{15} \mathrm{~N}^{19} \mathrm{~F}\right)$. The contraction for the $\mathrm{N} \ldots \mathrm{F}$ distance in $(\mathrm{CN})^{-} \ldots(\mathrm{H}-\mathrm{FLi})^{+}$causes an increase of ${ }^{3 \mathrm{~h}} \mathrm{~J}\left({ }^{13} \mathrm{C}^{19} \mathrm{~F}\right)$.

Table 8. Scalar coupling constants in $\mathrm{NCH} \cdots \mathrm{FLi}$ and $\mathrm{CNH} \cdots \mathrm{FLi}$ obtained at the gas phase and $\mathrm{PCM}=$ water approximations.

\begin{tabular}{|c|c|c|c|c|c|c|}
\hline Complex & $\begin{array}{c}{ }^{1} \mathrm{~J}\left({ }^{15} \mathrm{~N}^{13} \mathrm{C}\right) \\
\mathrm{Hz}\end{array}$ & $\begin{array}{c}\mathrm{J}\left({ }^{15} \mathrm{~N}^{1} \mathrm{H}\right) \\
\mathrm{Hz}\end{array}$ & $\begin{array}{c}\mathrm{J}\left({ }^{13} \mathrm{C}^{1} \mathrm{H}\right) \\
\mathrm{Hz}\end{array}$ & $\begin{array}{c}{ }^{1 \mathrm{~h}} \mathrm{~J}\left({ }^{1} \mathrm{H}^{19} \mathrm{~F}\right) \\
\mathrm{Hz}\end{array}$ & $\begin{array}{c}{ }^{\mathrm{h}} \mathrm{J}\left({ }^{13} \mathrm{C}^{19} \mathrm{~F}\right) \\
\mathrm{Hz}\end{array}$ & $\begin{array}{c}{ }^{\mathrm{h}} \mathrm{J}\left({ }^{15} \mathrm{~N}^{19} \mathrm{~F}\right) \\
\mathrm{Hz}\end{array}$ \\
\hline gas & & & & & & \\
\hline $\mathrm{NCH} \cdots \mathrm{FLi}$ & -22 & -12 & 256 & -66 & 146 & -7 \\
\hline $\begin{array}{l}\mathrm{CNH} \cdots \mathrm{FLi} \\
\text { water }\end{array}$ & -13 & -110 & 24 & -72 & 15 & -79 \\
\hline $\mathrm{NCH} \cdots \mathrm{FLi}$ & -20 & -12 & 232 & -109 & 252 & -17 \\
\hline $\mathrm{CNH} \cdots \mathrm{FLi}$ & -11 & -57 & 16 & 47 & 42 & -153 \\
\hline
\end{tabular}

The complex of hydrogen cyanide with tetrabutylammonium fluoride is the only complex that has so far been characterized in detail experimentally by means of NMR. The experimentally measured $\left|{ }^{1} \mathrm{~J}\left({ }^{15} \mathrm{~N}^{1} \mathrm{H}\right)\right|=92 \mathrm{~Hz}$ [60]. Consequently, this complex has the $\mathrm{CN}-\mathrm{H} \cdots \mathrm{F}^{-}$structure. Other coupling constants are $\left|{ }^{2 \mathrm{~h}} \mathrm{~J}\left({ }^{15} \mathrm{~N}^{19} \mathrm{~F}\right)\right|=61 \mathrm{~Hz}$, and $\left|{ }^{1 h} \mathrm{~J}\left({ }^{1} \mathrm{H}^{19} \mathrm{~F}\right)\right|=63 \mathrm{~Hz}$ [60]. The values of these three coupling constants are close to those calculated for $\mathrm{CN}-\mathrm{H} \cdots \mathrm{FLi}$ in the gas phase approximation, Table 8 . To a first approximation, this result again indicates that the values of these constants depend mainly on the distances and much less on considering the influence of the solvent field. However, the closeness of the experimental and calculated values should not be overestimated. Compare the expected changes in these coupling constants when going from $\mathrm{CN}-\mathrm{H} \cdots \mathrm{FLi}$ to $(\mathrm{CN})^{-} \ldots(\mathrm{H}-$ $\mathrm{FLi})^{+}$, Table $8 .{ }^{1} \mathrm{~J}\left({ }^{15} \mathrm{~N}^{1} \mathrm{H}\right)$ changes from $-110 \mathrm{~Hz}$ to $-57 \mathrm{~Hz}$. The experimental value $\left|{ }^{1} \mathrm{~J}\left({ }^{15} \mathrm{~N}^{1} \mathrm{H}\right)\right|=92 \mathrm{~Hz}$ is very reasonable. ${ }^{1 \mathrm{~h}} \mathrm{~J}\left({ }^{1} \mathrm{H}^{19} \mathrm{~F}\right)$ changes from $-72 \mathrm{~Hz}$ to $47 \mathrm{~Hz}$. The experimental value $\left|{ }^{1 \mathrm{~h}} \mathrm{~J}\left({ }^{1} \mathrm{H}^{19} \mathrm{~F}\right)\right|=63 \mathrm{~Hz}$ is consistent with the trend. ${ }^{2 \mathrm{~h}} \mathrm{~J}\left({ }^{15} \mathrm{~N}^{19} \mathrm{~F}\right)$ changes from $-79 \mathrm{~Hz}$ to $-153 \mathrm{~Hz}$. The experimental value $\left|{ }^{2 \mathrm{~h}} \mathrm{~J}\left({ }^{15} \mathrm{~N}^{19} \mathrm{~F}\right)\right|=61 \mathrm{~Hz}$ contradicts to the trend. Similar problems were observed for the complex of pyridine with hydrogen fluoride [50].

\subsection{Proton Bound Dimers of Cyanide}

Three proton bound dimers of cyanide are possible: $\left[\mathrm{NCHCN}^{-},[\mathrm{CNHCN}]^{-}\right.$, and $[\mathrm{CNHNC}]^{-}$. Note that the most energetically favorable structure of $\mathrm{HN}_{2} \mathrm{C}_{2}$ is $\mathrm{N} \equiv \mathrm{C}$ $\mathrm{C} \equiv \mathrm{NH}^{+}$. However, cyanogen does not form spontaneously in hydrogen cyanide solutions [97] and is not discussed here. Proton bound hydrogen cyanide homodimers and more complex clusters [98-100] are also not discussed here. 
$[\mathrm{NC} \cdots \mathrm{H} \cdots \mathrm{CN}]^{-}$is the energetically most favorable proton bound dimer of cyanide, Table 9 . In this centrosymmetric complex, the proton is equally strongly bound to both carbon atoms. The $\mathrm{N} \equiv \mathrm{C}$ and $\mathrm{C} \cdots \mathrm{H}$ distances are very short.

Table 9. The structure of $\mathrm{NC}^{-} \cdots \mathrm{HCN}, \mathrm{NC}^{-} \cdots \mathrm{HNC}$, and ${ }^{-} \mathrm{CN} \cdots \mathrm{HNC}$ complexes, their relative energies $\Delta \mathrm{E}$, the isotropic chemical shielding, $\sigma_{\text {iso }}$, the span, $\Omega$, of the shielding tensors, and scalar coupling constants obtained at $\mathrm{PCM}=$ water.

\begin{tabular}{|c|c|c|c|}
\hline Parameter & {$[\mathrm{NC} \cdots \mathrm{H} \cdots \mathrm{CN}]^{-}$} & {$[\mathrm{CN}]^{-} \cdots \mathrm{H}-\mathrm{CN}$} & {$[\mathrm{CN}]^{-} \cdots \mathrm{H}-\mathrm{NC}$} \\
\hline$\Delta \mathrm{E}, \mathrm{kJ} / \mathrm{mol}$ & 0 & 51 & 64 \\
\hline Base: $\mathrm{N} \equiv \mathrm{C}, \AA$ & 1.1515 & 1.1655 & 1.1611 \\
\hline Base: $\mathrm{X} \cdots \mathrm{H}, \AA$ & $1.2220^{1}$ & $1.1756^{2}$ & $1.4362^{2}$ \\
\hline Acid: H-Y, $\AA$ & $1.2220^{3}$ & $1.2917^{3}$ & $1.0847^{4}$ \\
\hline Acid: $\mathrm{N} \equiv \mathrm{C}, \AA$ & 1.1515 & 1.1528 & 1.1532 \\
\hline Base: $\sigma_{\text {iso }}\left({ }^{15} \mathrm{~N}\right)$, ppm & -6 & -17 & -22 \\
\hline Base: $\Omega\left({ }^{15} \mathrm{~N}\right), \mathrm{ppm}$ & 525 & 548 & 555 \\
\hline Acid: $\sigma_{\text {iso }}\left({ }^{15} \mathrm{~N}\right)$, ppm & -6 & -19 & 28 \\
\hline Acid: $\Omega\left({ }^{15} \mathrm{~N}\right), \mathrm{ppm}$ & 525 & 544 & 481 \\
\hline Base: $\sigma_{\text {iso }}\left({ }^{13} \mathrm{C}\right), \mathrm{ppm}$ & 32 & 21 & 16 \\
\hline Base: $\Omega\left({ }^{13} \mathrm{C}\right)$, ppm & 377 & 385 & 394 \\
\hline Acid: $\sigma_{\text {iso }}\left({ }^{13} \mathrm{C}\right), \mathrm{ppm}$ & 32 & 32 & 23 \\
\hline Acid: $\Omega\left({ }^{13} \mathrm{C}\right), \mathrm{ppm}$ & 377 & 376 & 382 \\
\hline Base: ${ }^{1} \mathrm{~J}\left({ }^{15} \mathrm{~N}^{13} \mathrm{C}\right), \mathrm{Hz}$ & -13 & -8 & -9 \\
\hline Acid: ${ }^{1} \mathrm{~J}\left({ }^{15} \mathrm{~N}^{13} \mathrm{C}\right), \mathrm{Hz}$ & -13 & -13 & -14 \\
\hline Base: $\mathrm{J}\left({ }^{13} \mathrm{C}^{1} \mathrm{H}\right), \mathrm{Hz}$ & 95 & 14 & 5 \\
\hline Acid: $\mathrm{J}\left({ }^{13} \mathrm{C}^{1} \mathrm{H}\right), \mathrm{Hz}$ & 95 & 95 & 24 \\
\hline Base: $\mathrm{J}\left({ }^{15} \mathrm{~N}^{1} \mathrm{H}\right), \mathrm{Hz}$ & -8 & -44 & -9 \\
\hline Acid: $\mathrm{J}\left({ }^{15} \mathrm{~N}^{1} \mathrm{H}\right), \mathrm{Hz}$ & -8 & -8 & -87 \\
\hline${ }^{2 \mathrm{~h}} \mathrm{~J}(\mathrm{XHY}), \mathrm{Hz}$ & $113^{5}$ & $-57^{6}$ & $20^{7}$ \\
\hline
\end{tabular}

${ }^{1} \mathrm{X}=\mathrm{C} .{ }^{2} \mathrm{X}=\mathrm{N} .{ }^{3} \mathrm{Y}=\mathrm{C} .{ }^{4} \mathrm{Y}=\mathrm{N} .{ }^{52 \mathrm{~h}} \mathrm{~J}\left({ }^{13} \mathrm{C}^{13} \mathrm{C}\right) \cdot{ }^{6 \mathrm{~h}} \mathrm{~J}\left({ }^{13} \mathrm{C}^{15} \mathrm{~N}\right) \cdot{ }^{72 \mathrm{~h}} \mathrm{~J}\left({ }^{15} \mathrm{~N}^{15} \mathrm{~N}\right)$.

The hetero- and homodimers $[\mathrm{CN}]^{-} \ldots \mathrm{H}-\mathrm{CN}$ and $[\mathrm{CN}]^{-} \ldots \mathrm{H}-\mathrm{NC}$ have similar energies and are asymmetric. The reason why some proton bound homodimers are symmetric and others not was explained in the past $[101,102]$ and recently reviewed [103]. In $\left[\mathrm{CN}^{-} \cdots \mathrm{H}^{-}\right.$ $\mathrm{CN}$, the hydrogen bond is stronger, and the position of the proton is more symmetric. In this complex the $\mathrm{N} \cdots \mathrm{H}$ distance is shorter than the $\mathrm{H}-\mathrm{C}$ distance. However, the $\mathrm{C} \equiv \mathrm{N}$ distance in the $[\mathrm{CN}]^{-}$unit is similar to that in free $[\mathrm{CN}]^{-}$, while in the $\mathrm{H}-\mathrm{CN}$ unit this distance is closer to that in free H-CN, Tables 1 and 9. For this reason, we call the former unit in this complex a base, and the latter an acid, regardless of the distance to the proton. The geometry of $[\mathrm{CN}]^{-} \cdots \mathrm{H}-\mathrm{NC}$ is similar to that of proton bound homodimers of pyridine [104] and its derivatives [105]. Some of the NMR parameters of this complex and its derivatives can be found elsewhere [106-108].

In all these complexes $\sigma_{\text {iso }}\left({ }^{13} \mathrm{C}\right), \Omega\left({ }^{13} \mathrm{C}\right), \sigma_{\text {iso }}\left({ }^{15} \mathrm{~N}\right)$ and $\Omega\left({ }^{15} \mathrm{~N}\right)$ are very similar and can hardly be used to characterize both the complexes and the specific units, except for $\mathrm{H}-\mathrm{NC}$ in $[\mathrm{CN}]^{-} \ldots \mathrm{H}-\mathrm{NC}$, Table 9 . Scalar couplings are more characteristic. Note how large ${ }^{2 \mathrm{~h}} \mathrm{~J}\left({ }^{13} \mathrm{C}^{13} \mathrm{C}\right)$ and ${ }^{2 \mathrm{~h}} \mathrm{~J}\left({ }^{13} \mathrm{C}^{15} \mathrm{~N}\right)$ can be across these hydrogen bonds.

\subsection{Solvation by the Cyanide Anions}

There are examples of hydrogen bonded aggregates in which several equal units are solvating one center. For example, aggregates $(\mathrm{FH})_{\mathrm{n}} \ldots \mathrm{F}^{-}$with $\mathrm{n} \leq 6$ were extensively investigated both experimentally and theoretically $[49,59,109,110]$. An increase in $n$ leads to a weakening of each of the hydrogen bonds due to the anticooperativity of their interaction. Here, this effect will be used to determine the amplitude of changes in NMR parameters that are possible for the same type of interaction.

The experimentally observed $\mathrm{CN}-\mathrm{H} \cdots \mathrm{F}^{-}$complex was discussed above. The energy of this complex is similar to that of $\mathrm{NC}-\mathrm{H} \cdots \mathrm{F}^{-}$, Table 10 . For larger $(\mathrm{CN}-\mathrm{H})_{\mathrm{n}} \cdots \mathrm{F}^{-}$and $(\mathrm{NC}-\mathrm{H})_{\mathrm{n}} \cdots \mathrm{F}^{-}$aggregates with $\mathrm{n}=2-4(\mathrm{NC}-\mathrm{H})_{\mathrm{n}} \cdots \mathrm{F}^{-}$are energetically more favorable 
because hydrogen cyanide has lower energy than isocyanide. Here we are interested whether it is possible to recognize aggregates with different $n$ by NMR. The geometry of these aggregates gradually changes with increasing $n$. These changes lead to changes in the NMR parameters. How large are the changes in the NMR parameters and are the trends of these changes monotonic?

Table 10. Geometry of $(\mathrm{NCH})_{n} \cdots \mathrm{F}^{-}$and $(\mathrm{CNH})_{n} \cdots \mathrm{F}^{-}$aggregates obtained at $\mathrm{PCM}=$ water.

\begin{tabular}{cccccccc}
\hline $\mathbf{n}$ & $\begin{array}{c}\mathbf{\Delta} \mathbf{E}^{\mathbf{1}} \\
\mathbf{k J} / \mathbf{m o l}\end{array}$ & $\mathbf{N} \equiv \mathbf{C}, \AA$ & $\begin{array}{c}(\mathbf{N C H})_{\mathbf{n}} \cdots \mathbf{F}^{-} \\
\mathbf{C} \cdots \mathbf{H}, \AA\end{array}$ & $\mathbf{H} \cdots \mathbf{F}, \AA$ & $\mathbf{C} \equiv \mathbf{N}, \AA$ & $\begin{array}{c}(\mathbf{C N H})_{\mathbf{n}} \cdots \mathbf{F}^{-} \\
\mathbf{N} \cdots \mathbf{H}, \AA\end{array}$ & $\mathbf{H} \cdots \mathbf{F}, \AA$ \\
\hline 1 & 4 & 1.1599 & 1.5754 & 1.0093 & 1.1636 & 1.5202 & 0.9875 \\
2 & 48 & 1.1485 & 1.1488 & 1.4674 & 1.1590 & 1.1086 & 1.3338 \\
3 & 93 & 1.1469 & 1.1197 & 1.5819 & 1.1584 & 1.0612 & 1.4651 \\
4 & 143 & 1.1461 & 1.1062 & 1.6621 & 1.1583 & 1.0412 & 1.5588 \\
\hline
\end{tabular}

${ }^{1}$ Relative energies $\Delta \mathrm{E}=\mathrm{E}(\mathrm{CNH}$-form $)-\mathrm{E}(\mathrm{NCH}$-form $)$

In $(\mathrm{NC}-\mathrm{H})_{\mathrm{n}} \cdots \mathrm{F}^{-}$with $\mathrm{n}=2-4$ all shielding parameters, $\sigma_{\text {iso }}\left({ }^{13} \mathrm{C}\right), \Omega\left({ }^{13} \mathrm{C}\right), \sigma_{\text {iso }}\left({ }^{15} \mathrm{~N}\right)$ and $\Omega\left({ }^{15} \mathrm{~N}\right)$, are similar for all $\mathrm{n}$ and can hardly be used to distinguish between these complexes, Table 11. In contrast, in $(\mathrm{CN}-\mathrm{H})_{n} \cdots \mathrm{F}^{-}$only for $\Omega\left({ }^{13} \mathrm{C}\right)$ the changes are small. The dependence of $\sigma_{\text {iso }}\left({ }^{15} \mathrm{~N}\right)$ and $\Omega\left({ }^{15} \mathrm{~N}\right)$ on the $\mathrm{N}$. . H distance is well known. Surprisingly, in this complex, $\sigma_{\text {iso }}\left({ }^{13} \mathrm{C}\right)$ also strongly depends on this distance. Note that these changes do not correlate with changes in the $\mathrm{N} \equiv \mathrm{C}$ distance, Table 10.

Table 11. The isotropic chemical shielding, $\sigma_{\text {iso }}$, and the span, $\Omega$, of the shielding tensors of the ${ }^{15} \mathrm{~N}$ and ${ }^{13} \mathrm{C}$ nuclei of $(\mathrm{NCH})_{n} \cdots \mathrm{F}^{-}$and $(\mathrm{CNH})_{n} \cdots \mathrm{F}^{-}$aggregates obtained at $\mathrm{PCM}=$ water.

\begin{tabular}{|c|c|c|c|c|c|c|c|c|}
\hline \multirow{3}{*}{ n } & \multicolumn{4}{|c|}{$(\mathrm{NCH})_{n} \cdots \mathrm{F}^{-}$} & \multicolumn{4}{|c|}{$(\mathrm{CNH})_{\mathrm{n}} \cdots \mathrm{F}^{-}$} \\
\hline & \multicolumn{2}{|c|}{${ }^{15} \mathrm{~N}, \mathrm{ppm}$} & \multicolumn{2}{|c|}{${ }^{13} \mathrm{C}, \mathrm{ppm}$} & \multicolumn{2}{|c|}{${ }^{15} \mathrm{~N}, \mathrm{ppm}$} & \multicolumn{2}{|c|}{${ }^{13} \mathrm{C}, \mathrm{ppm}$} \\
\hline & $\sigma_{\text {iso }}$ & $\Omega$ & $\sigma_{\text {iso }}$ & $\Omega$ & $\sigma_{\text {iso }}$ & $\Omega$ & $\sigma_{\text {iso }}$ & $\Omega$ \\
\hline 1 & -33 & 566 & 25 & 383 & -17 & 546 & 14 & 397 \\
\hline 2 & -15 & 537 & 51 & 344 & 34 & 470 & 20 & 386 \\
\hline 3 & -16 & 539 & 55 & 339 & 47 & 451 & 29 & 387 \\
\hline 4 & -18 & 540 & 57 & 336 & 55 & 440 & 18 & 389 \\
\hline
\end{tabular}

The composition of $(\mathrm{NC}-\mathrm{H})_{n} \cdots \mathrm{F}^{-}$can be clearly obtained using ${ }^{1} \mathrm{~J}\left({ }^{13} \mathrm{C}^{1} \mathrm{H}\right),{ }^{1 \mathrm{~h}} \mathrm{~J}\left({ }^{1} \mathrm{H}^{19} \mathrm{~F}\right)$, and ${ }^{2 \mathrm{~h}} \mathrm{~J}\left({ }^{13} \mathrm{C}^{19} \mathrm{~F}\right)$, Table 12. For $(\mathrm{CN}-\mathrm{H})_{\mathrm{n}} \cdots \mathrm{F}^{-}$the same can be done using ${ }^{1} \mathrm{~J}\left({ }^{15} \mathrm{~N}^{1} \mathrm{H}\right)$ and ${ }^{2 h} \mathrm{~J}\left({ }^{15} \mathrm{~N}^{19} \mathrm{~F}\right)$. The behavior of ${ }^{1 \mathrm{~h}} \mathrm{~J}\left({ }^{1} \mathrm{H}^{19} \mathrm{~F}\right)$ is not monotonic, Table 12 . The reason for this is as follows [59]. $\left.\mathrm{J}^{1} \mathrm{H}^{19} \mathrm{~F}\right)$ is very large and positive at short $\mathrm{H}$. . F distances. As this distance increases, $\mathrm{J}\left({ }^{1} \mathrm{H}^{19} \mathrm{~F}\right)$ decreases, goes through zero, and becomes negative. The absolute value of this coupling increases again, passes through a maximum, and then decreases to zero. In $(\mathrm{NC}-\mathrm{H})_{\mathrm{n}} \cdots \mathrm{F}^{-}$the $\mathrm{H} \ldots \mathrm{F}$ distances are larger than in $(\mathrm{CN}-\mathrm{H})_{\mathrm{n}} \cdots \mathrm{F}^{-}$for the same $\mathrm{n}$ and $\mathrm{J}\left({ }^{1} \mathrm{H}^{19} \mathrm{~F}\right)$ is close to its negative maximum already at $\mathrm{n}=2$, Tables 10 and 12 . However, $\mathrm{J}\left({ }^{1} \mathrm{H}^{19} \mathrm{~F}\right)$ does not depend exclusively on the $\mathrm{H}$. . F distance and differs in $(\mathrm{NC}-\mathrm{H})_{\mathrm{n}} \cdots \mathrm{F}^{-}$and $(\mathrm{CN}-\mathrm{H})_{n} \cdots \mathrm{F}^{-}$for the same $\mathrm{H} \ldots$ F distance. Note that the same behavior is observed for ${ }^{2 h} \mathrm{~J}\left({ }^{15} \mathrm{~N}^{19} \mathrm{~F}\right)$ in $(\mathrm{CN}-\mathrm{H})_{\mathrm{n}} \cdots \mathrm{F}^{-}$as $\mathrm{n}$ changes from 1 to 3 . The long range ${ }^{2 \mathrm{~h}} \mathrm{~J}\left({ }^{15} \mathrm{~N}^{1} \mathrm{H}\right),{ }^{2 \mathrm{~h}} \mathrm{~J}\left({ }^{13} \mathrm{C}^{1} \mathrm{H}\right)$, and ${ }^{3 \mathrm{~h}} \mathrm{~J}\left({ }^{15} \mathrm{~N}^{19} \mathrm{~F}\right)$ are similar for all $\mathrm{n}=2-4$. In contrast, ${ }^{3 \mathrm{~h}} \mathrm{~J}\left({ }^{13} \mathrm{C}^{19} \mathrm{~F}\right)$ varies greatly with $\mathrm{n} .{ }^{1} \mathrm{~J}\left({ }^{15} \mathrm{~N}^{13} \mathrm{C}\right)$ cannot be used to distinguish between different $\mathrm{n}=2-4$, but this coupling is characteristic for $(\mathrm{NC}-\mathrm{H})_{n} \cdots \mathrm{F}^{-}$and $(\mathrm{CN}-\mathrm{H})_{n} \cdots \mathrm{F}^{-}$. 
Table 12. Scalar coupling constants in $(\mathrm{NCH})_{n} \cdots \mathrm{F}^{-}$and $(\mathrm{CNH})_{n} \cdots \mathrm{F}^{-}$aggregates obtained at $\mathrm{PCM}=$ water.

\begin{tabular}{lcccccc}
\hline Complex & $\begin{array}{c}{ }^{\mathbf{1}} \mathbf{J}\left({ }^{\mathbf{1 5}} \mathbf{N}^{\mathbf{1 3}} \mathbf{C}\right), \\
\mathbf{H z}\end{array}$ & $\begin{array}{c}\mathbf{J}\left({ }^{\mathbf{1 5}} \mathbf{N}^{\mathbf{1}} \mathbf{H}\right), \\
\mathbf{H z}\end{array}$ & $\begin{array}{c}\mathbf{J}\left({ }^{\mathbf{1 3}} \mathbf{C}^{\mathbf{1}} \mathbf{H}\right), \\
\mathbf{H z}\end{array}$ & $\begin{array}{c}\mathbf{1 h}_{\mathbf{J}}\left({ }^{\mathbf{1}} \mathbf{H}^{\mathbf{1 9}} \mathbf{F}\right), \\
\mathbf{H z}\end{array}$ & $\begin{array}{c}\mathbf{h} \mathbf{J}\left({ }^{\mathbf{1 3}} \mathbf{C}^{\mathbf{1 9}} \mathbf{F}\right), \\
\mathbf{H z}\end{array}$ & $\begin{array}{c}{ }^{\mathbf{h}} \mathbf{J}\left({ }^{\mathbf{1 5}} \mathbf{N}^{\mathbf{1 9}} \mathbf{F}\right), \\
\mathbf{H z}\end{array}$ \\
\hline$(\mathrm{NCH}) \cdots{ }^{19} \mathrm{~F}^{-}$ & -10 & -2 & 31 & 291 & 314 & -22 \\
$(\mathrm{NCH})_{2} \cdots{ }^{19} \mathrm{~F}^{-}$ & -20 & -12 & 230 & -108 & 228 & -16 \\
$(\mathrm{NCH})_{3} \cdots{ }^{19} \mathrm{~F}^{-}$ & -22 & -12 & 250 & -87 & 171 & -11 \\
$(\mathrm{NCH})_{4} \cdots{ }^{19} \mathrm{~F}^{-}$ & -22 & -12 & 257 & -68 & 132 & -8 \\
$(\mathrm{CNH}) \cdots{ }^{19} \mathrm{~F}^{-}$ & -8 & -5 & 3 & 371 & 27 & -93 \\
$(\mathrm{CNH})_{2} \cdots{ }^{19} \mathrm{~F}^{-}$ & -13 & -87 & 22 & -67 & 29 & -109 \\
$(\mathrm{CNH})_{3} \cdots{ }^{19} \mathrm{~F}^{-}$ & -14 & -103 & 25 & -73 & 19 & -80 \\
$(\mathrm{CNH})_{4} \cdots{ }^{19} \mathrm{~F}^{-}$ & -15 & -110 & 25 & -61 & 13 & -58 \\
\hline
\end{tabular}

The cyanide anion is a quasisymmetric two-faced acceptor of interactions. How strong is the anticooperativity of such interactions? Here we compare $\left([\mathrm{NC}]^{-}\right)_{4} \cdots\left[\mathrm{H}_{4} \mathrm{~N}\right]^{+}$, $(\mathrm{LiNC})_{4} \cdots\left[\mathrm{H}_{4} \mathrm{~N}\right]^{+},\left([\mathrm{CN}]^{-}\right)_{4} \cdots\left[\mathrm{H}_{4} \mathrm{~N}\right]^{+}$, and $(\mathrm{LiCN})_{4} \cdots\left[\mathrm{H}_{4} \mathrm{~N}\right]^{+}$aggregates. The hydrogen bonds in $\left([\mathrm{NC}]^{-}\right)_{4} \cdots\left[\mathrm{H}_{4} \mathrm{~N}\right]^{+}$and $\left([\mathrm{CN}]^{-}\right)_{4} \cdots\left[\mathrm{H}_{4} \mathrm{~N}\right]^{+}$are weak. The C ... H and N ... H distances are large and the $\mathrm{N} \equiv \mathrm{C}$ distances are close to that in free $[\mathrm{C} \equiv \mathrm{N}]^{-}$, Tables 1 and 13. The energies of these aggregates are very similar. Although the addition of terminal Li cations weakens these bonds, the effect is small. At the same time, the presence of a new interaction can change the preferred orientation of the cyanide anions, Table 13.

Table 13. Geometry of $(\mathrm{NC})_{4}{ }^{3-} \ldots\left(\mathrm{H}_{4} \mathrm{~N}\right)^{+},(\mathrm{LiNC})_{4}{ }^{3-} \ldots\left(\mathrm{H}_{4} \mathrm{~N}\right)^{+},(\mathrm{CN})_{4}{ }^{3-} \ldots\left(\mathrm{H}_{4} \mathrm{~N}\right)^{+}$, and $(\mathrm{LiCN})_{4}{ }^{3-} \cdots\left(\mathrm{H}_{4} \mathrm{~N}\right)^{+}$hydrogen-bonded aggregates obtained at $\mathrm{PCM}=$ water.

\begin{tabular}{cccccccc}
\hline \multirow{2}{*}{$\mathrm{B}$} & \multirow{\Delta}{*}{$\mathrm{E}^{\mathbf{1}}$} & \multicolumn{3}{c}{$\left([\mathrm{BNC}]^{-}\right)_{\mathbf{4}} \cdots\left(\mathrm{NH}_{\mathbf{4}}\right)^{+}$} & \multicolumn{3}{c}{$\left([\mathrm{BCN}]^{-}\right)_{\mathbf{4}} \cdots\left(\mathbf{N H}_{4}\right)^{+}$} \\
& $\mathbf{k J} / \mathbf{m o l}$ & $\mathbf{N} \equiv \mathbf{C}, \AA$ & $\mathbf{C} \cdots \mathbf{H}, \AA$ & $\mathbf{N}-\mathbf{H}, \AA$ & $\mathrm{C} \equiv \mathbf{N}, \AA$ & $\mathbf{N} \cdots \mathbf{H}, \AA$ & $\mathbf{N}-\mathbf{H}, \AA$ \\
\hline $\mathrm{No}$ & -6 & 1.1644 & 2.0233 & 1.0400 & 1.1655 & 1.8751 & 1.0374 \\
$\mathrm{Li}^{+}$ & 10 & 1.1624 & 2.0295 & 1.0382 & 1.1615 & 1.8834 & 1.0359 \\
\hline
\end{tabular}

${ }^{1}$ Relative energies $\Delta \mathrm{E}=\mathrm{E}(\mathrm{CNH}$-form $)-\mathrm{E}(\mathrm{NCH}-$ form $)$.

Surprisingly, the presence of Li has a great impact on $\sigma_{i s o}\left({ }^{15} \mathrm{~N}\right)$ and $\Omega\left({ }^{15} \mathrm{~N}\right)$, regardless of whether it interacts with nitrogen or carbon atoms, Table 14 . Its impact on $\sigma_{\text {iso }}\left({ }^{13} \mathrm{C}\right)$ and $\Omega\left({ }^{13} \mathrm{C}\right)$ can be measurable but is smaller.

Table 14. The isotropic chemical shielding, $\sigma_{\text {iso }}$, and the span, $\Omega$, of the shielding tensors of the ${ }^{15} \mathrm{~N}$ and ${ }^{13} \mathrm{C}$ nuclei of $\left({ }^{15} \mathrm{~N} \equiv{ }^{13} \mathrm{C}\right)_{4}{ }^{3-} \cdots\left(\mathrm{H}_{4} \mathrm{~N}\right)^{+},\left(\mathrm{Li}^{15} \mathrm{~N} \equiv{ }^{13} \mathrm{C}\right)_{4} \cdots\left(\mathrm{H}_{4} \mathrm{~N}\right)^{+},\left({ }^{13} \mathrm{C} \equiv{ }^{15} \mathrm{~N}\right)_{4}{ }^{3-} \cdots\left(\mathrm{H}_{4} \mathrm{~N}\right)^{+}$, and $\left(\mathrm{Li}^{13} \mathrm{C} \equiv{ }^{15} \mathrm{~N}\right)_{4} \cdots\left(\mathrm{H}_{4} \mathrm{~N}\right)^{+}$aggregates obtained at $\mathrm{PCM}=$ water.

\begin{tabular}{|c|c|c|c|c|c|c|c|c|}
\hline \multirow{3}{*}{ B } & \multicolumn{4}{|c|}{$\left(\left[\mathrm{B}^{15} \mathrm{~N} \equiv{ }^{13} \mathrm{C}\right]^{-}\right)_{4} \cdots\left(\mathrm{NH}_{4}\right)^{+}$} & \multicolumn{4}{|c|}{$\left(\left[\mathrm{B}^{13} \mathrm{C} \equiv{ }^{15} \mathrm{~N}\right]^{-}\right)_{4} \cdots\left(\mathrm{NH}_{4}\right)^{+}$} \\
\hline & \multicolumn{2}{|c|}{${ }^{15} \mathrm{~N}$, ppm } & \multicolumn{2}{|c|}{${ }^{13} \mathrm{C}, \mathrm{ppm}$} & \multicolumn{2}{|c|}{${ }^{15} \mathrm{~N}, \mathrm{ppm}$} & \multicolumn{2}{|c|}{${ }^{13} \mathrm{C}, \mathrm{ppm}$} \\
\hline & $\sigma_{\text {iso }}$ & $\Omega$ & $\sigma_{\text {iso }}$ & $\Omega$ & $\sigma_{\text {iso }}$ & $\Omega$ & $\sigma_{\text {iso }}$ & $\Omega$ \\
\hline No & -37 & 572 & 15 & 398 & -39 & 579 & 13 & 399 \\
\hline $\mathrm{Li}^{+}$ & -109 & 691 & 27 & 384 & 4 & 520 & 35 & 378 \\
\hline
\end{tabular}

Scalar couplings in these aggregates are small and are not easy to measure, Table 15. However, the value of ${ }^{1} \mathrm{~J}\left({ }^{15} \mathrm{~N}^{13} \mathrm{C}\right)$ in $\left(\mathrm{Li}^{13} \mathrm{C} \equiv{ }^{15} \mathrm{~N}\right)_{4} \cdots\left(\mathrm{H}_{4}{ }^{15} \mathrm{~N}\right)^{+}$is very remarkable. It shows that this coupling increases above $15 \mathrm{~Hz}$ when the carbon atom participates in a strong interaction and remains below $15 \mathrm{~Hz}$ when such interaction is either weak or directed towards the nitrogen atom, Tables 1 and 15. 
Table 15. Scalar coupling constants in $\left({ }^{15} \mathrm{~N} \equiv{ }^{13} \mathrm{C}\right)_{4}{ }^{3-} \ldots\left({ }^{1} \mathrm{H}_{4}{ }^{15} \mathrm{~N}\right)^{+},\left(\mathrm{Li}^{15} \mathrm{~N} \equiv{ }^{13} \mathrm{C}\right){ }_{4}{ }^{3-} \ldots\left({ }^{1} \mathrm{H}_{4}{ }^{15} \mathrm{~N}\right)^{+}$, $\left({ }^{13} \mathrm{C} \equiv{ }^{15} \mathrm{~N}\right){ }_{4}{ }^{3-} \ldots\left({ }^{1} \mathrm{H}_{4}{ }^{15} \mathrm{~N}\right)^{+}$, and $\left(\mathrm{Li}^{13} \mathrm{C} \equiv{ }^{15} \mathrm{~N}\right){ }_{4}{ }^{3-} \ldots\left({ }^{1} \mathrm{H}_{4}{ }^{15} \mathrm{~N}\right)^{+}$aggregates obtained at $\mathrm{PCM}=$ water.

\begin{tabular}{|c|c|c|c|c|c|}
\hline Complex & $\begin{array}{c}{ }^{1} \mathrm{~J}\left({ }^{15} \mathrm{~N}^{13} \mathrm{C}\right) \\
\mathrm{Hz}\end{array}$ & $\begin{array}{c}{ }^{h} \mathrm{~J}\left({ }^{15} \mathrm{~N}^{1} \mathrm{H}\right), \\
\mathrm{Hz}\end{array}$ & $\begin{array}{c}{ }^{h} \mathrm{~J}\left({ }^{13} \mathrm{C}^{1} \mathrm{H}\right), \\
\mathrm{Hz}\end{array}$ & $\begin{array}{c}{ }^{\mathrm{h}} \mathrm{J}\left({ }^{13} \mathrm{C}^{15} \mathrm{~N}\right) \\
\mathrm{Hz}\end{array}$ & 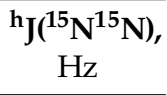 \\
\hline$\left(\left[{ }^{15} \mathrm{~N} \equiv{ }^{13} \mathrm{C}\right]^{-}\right)_{4} \cdots\left(\mathrm{H}_{4}{ }^{15} \mathrm{~N}\right)^{+}$ & -9 & 0 & -7 & -15 & 1 \\
\hline$\left(\mathrm{Li}^{15} \mathrm{~N} \equiv{ }^{13} \mathrm{C}\right)_{4} \cdots\left(\mathrm{H}_{4}{ }^{15} \mathrm{~N}\right)^{+}$ & -5 & -1 & -6 & -15 & 0 \\
\hline$\left(\left[{ }^{13} \mathrm{C} \equiv{ }^{15} \mathrm{~N}\right]^{-}\right)_{4} \cdots\left(\mathrm{H}_{4}{ }^{15} \mathrm{~N}\right)^{+}$ & -7 & 5 & 0 & -1 & 6 \\
\hline$\left(\mathrm{Li}^{13} \mathrm{C} \equiv{ }^{15} \mathrm{~N}\right)_{4} \cdots\left(\mathrm{H}_{4}{ }^{15} \mathrm{~N}\right)^{+}$ & -17 & 4 & 0 & -1 & 5 \\
\hline
\end{tabular}

\section{Conclusions}

This work reports on the geometry and NMR parameters of hydrogen cyanide and isocyanide hydrogen bonded to proton acceptors, whose ability to accept protons was distributed over a wide range. The main objective of this study was to find NMR parameters that can be used to unambiguously determine the structure of such complexes. The most important conclusions are as follows.

For weak proton acceptors, the most energetically favorable structure is NC-H...X. The NMR parameters of such structures are similar to those of free hydrogen cyanide. The most characteristic parameters of these structures are ${ }^{1} \mathrm{~J}\left({ }^{13} \mathrm{C}^{1} \mathrm{H}\right)>200 \mathrm{~Hz}$ and $\left|{ }^{1} \mathrm{~J}\left({ }^{15} \mathrm{~N}^{13} \mathrm{C}\right)\right|>20 \mathrm{~Hz}$.

For strong proton acceptors, the most energetically favorable structure may be $C \equiv N \cdots H \cdots X$. The most characteristic parameters of these structures are the ${ }^{15} \mathrm{~N}$ isotropic chemical shift, the span of the ${ }^{15} \mathrm{~N}$ chemical shift tensor, and ${ }^{1} \mathrm{~J}\left({ }^{15} \mathrm{~N}^{1} \mathrm{H}\right)$.

When the cyanide anion interacts with weak acids, both $[\mathrm{NC}]^{-} \cdot \mathrm{H}-\mathrm{X}$ and $\left[\mathrm{CN}^{-}{ }^{-} \cdot \mathrm{H}^{-}\right.$ $X$ structures are equally possible. The NMR parameters of such structures are similar to those of free cyanide anion. However, if the terminal nitrogen atom in $[\mathrm{NC}]^{-} \ldots \mathrm{H}-\mathrm{X}$ participates in an additional interaction, its chemical shift can vary greatly.

The most energetically favorable structure of a complex of hydrogen cyanide and the cyanide anion is symmetric, $[\mathrm{NC} \cdots \mathrm{H} \cdots \mathrm{CN}]^{-}$, with ${ }^{1 \mathrm{~h}} \mathrm{~J}\left({ }^{13} \mathrm{C}^{1} \mathrm{H}\right)$ about $100 \mathrm{~Hz}$.

The spin-spin coupling across the $\mathrm{N} \equiv \mathrm{C}$ bond, ${ }^{1} \mathrm{~J}\left({ }^{15} \mathrm{~N}^{13} \mathrm{C}\right)$ strongly correlates with the bond length and can be used to identify the structure of hydrogen bonded complexes in cases where other spin-spin couplings are averaged to zero due to proton and molecular exchange, Figure 2. Deviations from this correlation are possible only if both atoms participate in external interactions.

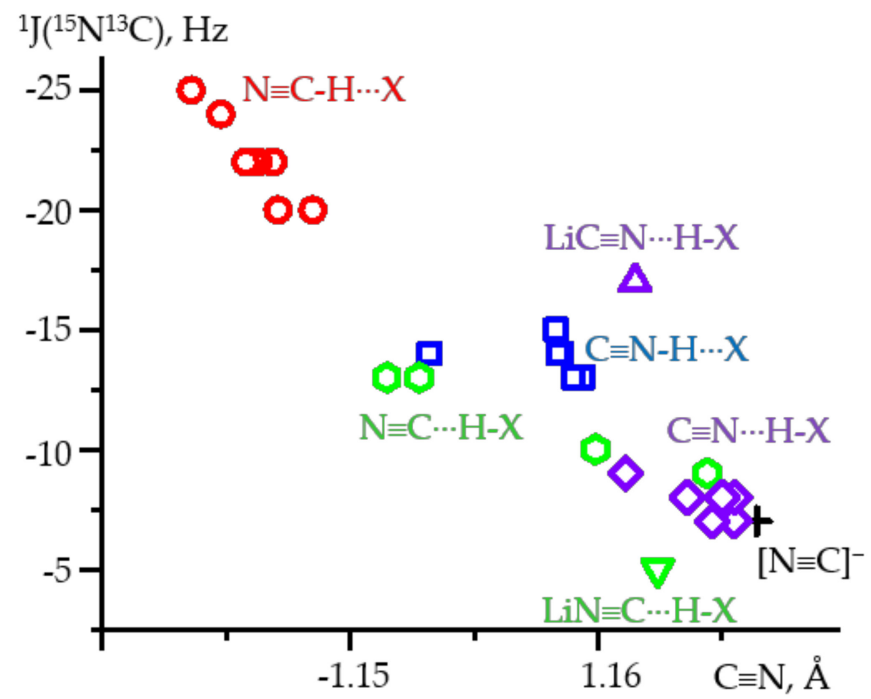

Figure 2. The ${ }^{1} \mathrm{~J}\left({ }^{15} \mathrm{~N}^{13} \mathrm{C}\right)$ spin-spin coupling as a function of the $\mathrm{N} \equiv \mathrm{C}$ distance in different hydrogen

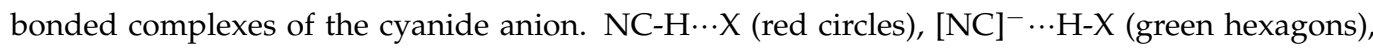
$\mathrm{CN}-\mathrm{H} \cdots \mathrm{X}$ (blue squares), $[\mathrm{CN}]^{-} \cdots \mathrm{H}-\mathrm{X}$ (violet diamonds), LiNC $\cdots \mathrm{H}-\mathrm{X}$ (green down triangle), and $\mathrm{LiCN} \cdots \mathrm{H}-\mathrm{X}$ (violet up triangle). 
Author Contributions: Conceptualization, I.G.S.; methodology, I.G.S. and G.S.D.; data curation, G.S.D.; writing—original draft preparation, I.G.S.; writing—review and editing, G.S.D.; visualization, I.G.S.; supervision, I.G.S. All authors have read and agreed to the published version of the manuscript.

Funding: This research was funded by the Russian Foundation of Basic Research (Project 20-03-00231).

Institutional Review Board Statement: Not applicable.

Informed Consent Statement: Not applicable.

Data Availability Statement: Data sharing is not applicable to this article.

Acknowledgments: The authors gratefully acknowledge the Gauss Centre for Supercomputing e.V. (www.gauss-centre.eu accessed on 17 June 2021) for funding this project by providing computing time on the GCS Supercomputer SuperMUC at Leibniz Supercomputing Centre (LRZ, www.lrz.de (accessed on 19 July 2021)).

Conflicts of Interest: The author declares no conflict of interest.

\section{References}

1. Patel, B.H.; Percivalle, C.; Ritson, D.J.; Duffy, C.D.; Sutherland, J.D. Common origins of RNA, protein and lipid precursors in a cyanosulfidic protometabolism. Nat. Chem. 2015, 7, 301-307. [CrossRef]

2. Perrin, Z.; Carrasco, N.; Chatain, A.; Jovanovic, L.; Vettier, L.; Ruscassier, N.; Cernogora, G. An Atmospheric Origin for HCN-Derived Polymers on Titan. Processes 2021, 9, 965. [CrossRef]

3. Akimov, M.G.; Fomina-Ageeva, E.V.; Dudina, P.V.; Andreeva, L.A.; Myasoyedov, N.F.; Bezuglov, V.V. ACTH(6-9)PGP Peptide Protects SH-SY5Y Cells from $\mathrm{H}_{2} \mathrm{O}_{2}$, tert-Butyl Hydroperoxide, and Cyanide Cytotoxicity via Stimulation of Proliferation and Induction of Prosurvival-Related Genes. Molecules 2021, 26, 1878. [CrossRef] [PubMed]

4. Leavesley, H.B.; Li, L.; Prabhakaran, K.; Borowitz, J.L.; Isom, G.E. Interaction of Cyanide and Nitric Oxide with Cytochrome c Oxidase: Implications for Acute Cyanide Toxicity. Tox. Sci. 2008, 101, 101-111. [CrossRef] [PubMed]

5. Donato, D.B.; Nichols, O.; Possingham, H.; Moore, M.; Ricci, P.F.; Noller, B.N. A critical review of the effects of gold cyanidebearing tailings solutions on wildlife. Environ. Int. 2007, 33, 974-984. [CrossRef]

6. Meot-Ner, M. The ionic hydrogen bond. Chem. Rev. 2005, 105, 213-284. [CrossRef]

7. Chen, J.-Y.; Yoo, C.-S. Physical and chemical transformations of sodium cyanide at high pressures. J. Chem. Phys. 2009, 131, 144507. [CrossRef] [PubMed]

8. Kuhn, N.; Eichele, K.; Steimann, M.; Al-Sheikh, A.; Doser, B.; Ochsenfeld, C. Hydrogen bonds with cyanide ions? The structures of 1,3-diisopropyl-4,5-dimethylimidazolium cyanide and 1-isopropyl-3,4,5-trimethylimidazolium cyanide. Z. Anorg. Allg. Chem. 2006, 632, 2268-2275. [CrossRef]

9. Černák, J.; Orendáč, M.; Potočňák, I.; Chomič, J.; Orendáčová, A.; Skoršepa, J.; Feher, A. Cyanocomplexes with one-dimensional structures: Preparations, crystal structures and magnetic properties. Coord. Chem. Rev. 2002, 224, 51-66. [CrossRef]

10. Markley, T.J.; Toby, B.H.; Pearlstein, R.M.; Ramprasad, D. New Synthesis Routes to Lithium and Cesium Cyanide Salts. Inorg. Chem. 1997, 36, 3376-3378. [CrossRef]

11. Lely, J.A.; Bijvoet, J.M. The crystal structure of lithium cyanide. Recl. Trav. Chim. Pays Bas 1942, 61, 244-252. [CrossRef]

12. Ruiz-Bermejo, M.; de la Fuente, J.L.; Pérez-Fernández, C.; Mateo-Martí, E. A Comprehensive Review of HCN-Derived Polymers. Processes 2021, 9, 597. [CrossRef]

13. Fernández, A.; Ruiz-Bermejo, M.; de la Fuente, J.L. Modelling the kinetics and structural property evolution of a versatile reaction: Aqueous HCN polymerization. Phys. Chem. Chem. Phys. 2018, 20, 17353-17366. [CrossRef]

14. Mamajanov, I.; Herzfeld, J. HCN polymers characterized by SSNMR: Solid state reaction of crystalline tetramer (diaminomaleonitrile). J. Chem. Phys. 2009, 130, 134504. [CrossRef] [PubMed]

15. Mamajanov, I.; Herzfeld, J. HCN polymers characterized by solid state NMR: Chains and sheets formed in the neat liquid. J. Chem. Phys. 2009, 130, 134503. [CrossRef]

16. Bläsing, K.; Bresien, J.; Labbow, R.; Schulz, A.; Villinger, A. A Dimer of Hydrogen Cyanide Stabilized by a Lewis Acid. Angew. Chem. Int. Ed. 2018, 57, 9170-9175. [CrossRef] [PubMed]

17. Alfredsson, M.; Ojamäe, L.; Hermansson, K.G. A comparison of Hartree-Fock, MP2, and DFT results for the HCN dimer and crystal. Int. J. Quantum Chem. 1996, 60, 767-778. [CrossRef]

18. Buxton, L.W.; Campbell, E.J.; Flygare, W.H. The vibrational ground state rotational spectroscopic constants and structure of the HCN dimer. Chem. Phys. 1981, 56, 399-406. [CrossRef]

19. de Oliveira, P.M.C.; Silva, J.A.; Longo, R.L. Benchmark, DFT assessments, cooperativity, and energy decomposition analysis of the hydrogen bonds in HCN/HNC oligomeric complexes. J. Mol. Model. 2017, 23, 1-10. [CrossRef]

20. King, B.F.; Weinhold, F. Structure and spectroscopy of $(\mathrm{HCN})_{\mathrm{n}}$ clusters: Cooperative and electronic delocalization effects in C-H $\cdots$ N hydrogen bonding. J. Chem. Phys. 1995, 103, 333-347. [CrossRef]

21. Dulmage, W.J.; Lipscomb, W.N. The crystal structures of hydrogen cyanide, HCN. Acta Cryst. 1951, 4, 330-334. [CrossRef] 
22. Bläsing, K.; Harloff, J.; Schulz, A.; Stoffers, A.; Stoer, P.; Villinger, A. Salts of HCN-Cyanide Aggregates: $\left[\mathrm{CN}(\mathrm{HCN})_{2}\right]^{-}$and $\left[\mathrm{CN}(\mathrm{HCN})_{3}\right]^{-}$. Angew. Chem. Int. Ed. 2020, 59, 10508-10513. [CrossRef] [PubMed]

23. Grabowski, S.J. Hydrogen Bonds with $\mathrm{BF}_{4}{ }^{-}$Anion as a Proton Acceptor. Crystals 2020, 10, 460. [CrossRef]

24. Szatyłowicz, H.; Krygowski, T.M.; Fonseca Guerra, C.; Bickelhaupt, F.M. Complexes of 4-substituted phenolates with HF and HCN: Energy decomposition and electronic structure analyses of hydrogen bonding. J. Comput. Chem. 2013, 34, 696-705. [CrossRef]

25. McDowell, S.A.; Buckingham, A.D. Cooperative and diminutive hydrogen bonding in $\mathrm{Y} \cdots \mathrm{HCN} \cdots \mathrm{HCN}$ and NCH$\cdots \mathrm{Y} \cdots$ HCN trimers (Y=BF, CO, N 2 ). J. Chem. Phys. 2010, 132, 064303. [CrossRef] [PubMed]

26. Clutter, D.R.; Thompson, W.E. Infrared spectroscopic study of polycrystalline $\mathrm{NH}_{4}$ CN. J. Chem. Phys. 1969, 51, 153-159. [CrossRef]

27. Şahin, Ö.; Özdemir, Ü.Ö.; Seferoğlu, N.; Aydıner, B.; Sarı, M.; Tunç, T.; Seferoğlu, Z. A highly selective and sensitive chemosensor derived coumarin-thiazole for colorimetric and fluorimetric detection of $\mathrm{CN}^{-}$ion in DMSO and aqueous solution: Synthesis, sensing ability, $\mathrm{Pd}(\mathrm{II}) / \mathrm{Pt}(\mathrm{II})$ complexes and theoretical studies. Tetrahedron 2016, 72, 5843-5852. [CrossRef]

28. Li, J.J.; Wei, W.; Qi, X.L.; Xu, X.; Liu, Y.C.; Lin, Q.H.; Dong, W. Rational design, synthesis of reaction-based dual-channel cyanide sensor in aqueous solution. Spectrochim. Acta A 2016, 152, 288-293. [CrossRef]

29. Rybarczyk-Pirek, A.J.; Małecka, M.; Palusiak, M. Use of Quantum Theory of Atoms in Molecules in the Search for Appropriate Hydrogen Atom Locations in X-ray Diffraction Based Studies. Cryst. Growth Des. 2016, 16, 6841-6848. [CrossRef]

30. Li, J.; Qi, X.; Wei, W.; Liu, Y.; Xu, X.; Lin, Q.; Dong, W. A “donor-two-acceptor” sensor for cyanide detection in aqueous solution. Sens. Actuators B Chem. 2015, 220, 986-991. [CrossRef]

31. Le Questel, J.Y.; Berthelot, M.; Laurence, C. Hydrogen-bond acceptor properties of nitriles: A combined crystallographic and ab initio theoretical investigation. J. Phys. Org. Chem. 2000, 13, 347-358. [CrossRef]

32. Herail, M.; Berthelot, M.; Proutiere, A. Prediction of hydrogen bond basicity in nitriles from dipole moments, mesomeric effects and electrostatic potentials. J. Phys. Org. Chem. 1995, 8, 421-428. [CrossRef]

33. Bechtel, H.A.; Steeves, A.H.; Wong, B.M.; Field, R.W. Evolution of chemical bonding during HCN $\rightleftarrows$ HNC isomerization as revealed through nuclear quadrupole hyperfine structure. Angew. Chem. Int. Ed. 2008, 47, 2969-2972. [CrossRef] [PubMed]

34. Wong, B.M. Nuclear quadrupole hyperfine structure in $\mathrm{HC}^{14} \mathrm{~N} / \mathrm{H}^{14} \mathrm{NC}$ and $\mathrm{DC}^{15} \mathrm{~N} / \mathrm{D}^{15} \mathrm{NC}$ isomerization: A diagnostic tool for characterizing vibrational localization. Phys. Chem. Chem. Phys. 2008, 10, 5599-5606. [CrossRef] [PubMed]

35. Stokes, H.T.; Ailion, D.C.; Case, T.A. Molecular reorientations in the ordered phases of KCN and NaCN studied by NMR. Phys. Rev. B 1984, 30, 4925. [CrossRef]

36. Geisheimer, A.R.; Wren, J.E.; Michaelis, V.K.; Kobayashi, M.; Sakai, K.; Kroeker, S.; Leznoff, D.B. Aggregation of $\left[\mathrm{Au}(\mathrm{CN})_{4}\right]^{-}$ Anions: Examination by Crystallography and ${ }^{15} \mathrm{~N}$ CP-MAS NMR and the Structural Factors Influencing Intermolecular Au $\cdots \mathrm{N}$ Interactions. Inorg. Chem. 2011, 50, 1265-1274. [CrossRef]

37. Seliman, A.A.; Altaf, M.; Kawde, A.N.; Wazeer, M.I.; Isab, A.A. NMR and kinetic studies of the interactions of [Au(cis$\left.\mathrm{DACH}) \mathrm{Cl}_{2}\right] \mathrm{Cl}$ and $\left[\mathrm{Au}(\text { cis-DACH})_{2}\right] \mathrm{Cl}_{3}$ with potassium cyanide in aqueous solution. J. Coord. Chem. 2014, 67, 3431-3443. [CrossRef]

38. He, C.; Smith, M.A. A comprehensive NMR structural study of Titan aerosol analogs: Implications for Titan's atmospheric chemistry. Icarus 2014, 243, 31-38. [CrossRef]

39. Werner-Zwanziger, U.; Chapman, K.W.; Zwanziger, J. Multinuclear NMR study of zinc dicyanide. Z. Phys. Chem. 2012, 226, 1205-1218. [CrossRef]

40. Shaikh, M.N.; Al-Maythalony, B.A.; Monim-Ul-Mehboob, M.; Fettouhi, M.; Wazeer, M.I.; Isab, A.A.; Ahmad, S. Mercury (II) cyanide complexes with alkyldiamines: Solid-state/solution NMR, computational, and antimicrobial studies. J. Coord. Chem. 2012, 65, 2074-2086. [CrossRef]

41. He, C.; Lin, G.; Upton, K.T.; Imanaka, H.; Smith, M.A. Structural investigation of HCN polymer isotopomers by solution-state multidimensional NMR. J. Phys. Chem. A 2012, 116, 4751-4759. [CrossRef]

42. Cabral, B.J. Born-Oppenheimer molecular dynamics, hydrogen bond interactions and magnetic properties of liquid hydrogen cyanide. J. Mol. Liq. 2018, 272, 778-786. [CrossRef]

43. Alkorta, I.; Rozas, I.; Elguero, J. Isocyanides as hydrogen bond acceptors. Theor. Chem. Acc. 1998, 99, 116-123. [CrossRef]

44. Lorente, P.; Shenderovich, I.G.; Golubev, N.S.; Denisov, G.S.; Buntkowsky, G.; Limbach, H.-H. ${ }^{1} \mathrm{H} /{ }^{15} \mathrm{~N}$ NMR Chemical Shielding, Dipolar ${ }^{15} \mathrm{~N},{ }^{2} \mathrm{H}$ Coupling and Hydrogen Bond Geometry Correlations in a Novel Serious of Hydrogen-Bonded Acid-Base Complexes of Collidine with Carboxylic Acids. Magn. Reson. Chem. 2001, 39, S18-S29. [CrossRef]

45. Solum, M.S.; Altmann, K.L.; Strohmeier, M.; Berges, D.A.; Zhang, Y.; Facelli, J.C.; Pugmire, R.J.; Grant, D.M. ${ }^{15}$ N Chemical Shift Principal Values in Nitrogen Heterocycles. J. Am. Chem. Soc. 1997, 119, 9804-9809. [CrossRef]

46. Gurinov, A.A.; Rozhkova, Y.A.; Zukal, A.; Čejka, J.; Shenderovich, I.G. Mutable Lewis and Brønsted Acidity of Aluminated SBA-15 as Revealed by NMR of Adsorbed Pyridine- ${ }^{15}$ N. Langmuir 2011, 27, 12115-12123. [CrossRef]

47. Gräfenstein, J. Efficient calculation of NMR isotopic shifts: Difference-dedicated vibrational perturbation theory. J. Chem. Phys. 2019, 151, 244120. [CrossRef]

48. Golubev, N.S.; Melikova, S.M.; Shchepkin, D.N.; Shenderovich, I.G.; Tolstoy, P.M.; Denisov, G.S. Interpretation of H/D Isotope Effects on NMR Chemical Shifts of [FHF] ${ }^{-}$Ion Based on Calculations of Nuclear Magnetic Shielding Tensor Surface. Z. Phys. Chem. 2003, 217, 1549-1563. [CrossRef] 
49. Shenderovich, I.G.; Limbach, H.-H.; Smirnov, S.N.; Tolstoy, P.M.; Denisov, G.S.; Golubev, N.S. H/D Isotope Effects on the Low-Temperature NMR Parameters and Hydrogen Bond Geometries of $(\mathrm{FH})_{2} \mathrm{~F}^{-}$and $(\mathrm{FH})_{3} \mathrm{~F}^{-}$Dissolved in $\mathrm{CDF}_{3} / \mathrm{CDF}_{2} \mathrm{Cl}_{\text {. }}$ Phys. Chem. Chem. Phys. 2002, 4, 5488-5497. [CrossRef]

50. Shenderovich, I.G.; Denisov, G.S. Solvent effects on acid-base complexes. What is more important: A macroscopic reaction field or solute-solvent interactions? J. Chem. Phys. 2019, 150, 204505. [CrossRef]

51. Gurinov, A.A.; Denisov, G.S.; Borissova, A.O.; Goloveshkin, A.S.; Greindl, J.; Limbach, H.-H.; Shenderovich, I.G. NMR Study of Solvation Effect on the Geometry of Proton-Bound Homodimers of Increasing Size. J. Phys. Chem. A 2017, 121, 8697-8705. [CrossRef]

52. Lesnichin, S.B.; Tolstoy, P.M.; Limbach, H.-H.; Shenderovich, I.G. Counteranion-Dependent Mechanisms of Intramolecular Proton Transfer in Aprotic Solution. Phys. Chem. Chem. Phys. 2010, 12, 10373-10379. [CrossRef]

53. Shenderovich, I.G. Electric field effect on ${ }^{31}$ P NMR magnetic shielding. J. Chem. Phys. 2020, 153, 184501. [CrossRef]

54. Alkorta, I.; Elguero, J.; Denisov, G.S. A review with comprehensive data on experimental indirect scalar NMR spin-spin coupling constants across hydrogen bonds. Magn. Res. Chem. 2008, 46, 599-624. [CrossRef] [PubMed]

55. Del Bene, J.E.; Elguero, J. Probing the proton-transfer coordinate of complexes with F-H ... P hydrogen bonds using one-and two-bond spin-spin coupling constants. Magn. Res. Chem. 2007, 45, 714-719. [CrossRef] [PubMed]

56. Alkorta, I.; Elguero, J. Review on DFT and ab initio Calculations of Scalar Coupling Constants. Int. J. Mol. Sci. 2003, 4, 64-92. [CrossRef]

57. Golubev, N.S.; Shenderovich, I.G.; Smirnov, S.N.; Denisov, G.S.; Limbach, H.-H. Nuclear Scalar Spin-Spin Coupling Reveals Novel Properties of Low-Barrier Hydrogen Bonds in a Polar Environment. Chem. Eur. J. 1999, 5, 492-497. [CrossRef]

58. Dingley, A.J.; Grzesiek, S. Direct observation of hydrogen bonds in nucleic acid base pairs by internucleotide ${ }^{2} \mathrm{~J}_{\mathrm{NN}}$ couplings. J. Am. Chem. Soc. 1998, 120, 8293-8297. [CrossRef]

59. Shenderovich, I.G.; Smirnov, S.N.; Denisov, G.S.; Gindin, V.A.; Golubev, N.S.; Dunger, A.; Reibke, R.; Kirpekar, S.; Malkina, O.L.; Limbach, H.-H. Nuclear Magnetic Resonance of Hydrogen Bonded Clusters between $\mathrm{F}^{-}$and $(\mathrm{HF})_{\mathrm{n}}$ : Experiment and Theory. Ber. Bunsenges. Phys. Chem. Chem. Phys. 1998, 102, 422-428. [CrossRef]

60. Golubev, N.S.; Detering, C.; Smirnov, S.N.; Shenderovich, I.G.; Denisov, G.S.; Limbach, H.-H.; Tolstoy, P.M. H/D Isotope Effects on NMR Chemical Shifts of Nuclei Involved in a Hydrogen Bridge of Hydrogen Isocyanide Complexes with Fluoride Anion. Phys. Chem. Chem. Phys. 2009, 11, 5154-5159. [CrossRef]

61. Begimova, G.U.; Tupikina, E.Y.; Yu, V.K.; Denisov, G.S.; Bodensteiner, M.; Shenderovich, I.G. Effect of Hydrogen Bonding to Water on the ${ }^{31} \mathrm{P}$ Chemical Shift Tensor of Phenyl- and Trialkylphosphine Oxides and a-Amino Phosphonates. J. Phys. Chem. C 2016, 120, 8717-8729. [CrossRef]

62. Shenderovich, I.G. Effect of Noncovalent Interactions on the ${ }^{31} \mathrm{P}$ Chemical Shift Tensor of Phosphine Oxides, Phosphinic, Phosphonic, and Phosphoric Acids, and Their Complexes with Lead(II). J. Phys. Chem. C 2013, 117, 26689-26702. [CrossRef]

63. Shenderovich, I.G. For Whom a Puddle Is the Sea? Adsorption of Organic Guests on Hydrated MCM-41 Silica. Langmuir 2020, 36, 11383-11392. [CrossRef] [PubMed]

64. Shenderovich, I.G.; Buntkowsky, G.; Schreiber, A.; Gedat, E.; Sharif, S.; Albrecht, J.; Golubev, N.S.; Findenegg, G.H.; Limbach, H.-H. Pyridine- ${ }^{15} \mathrm{~N}-$ A Mobile NMR Sensor for Surface Acidity and Surface Defects of Mesoporous Silica. J. Phys. Chem. B 2003, 107, 11924-11939. [CrossRef]

65. Frisch, M.J.; Trucks, G.W.; Schlegel, H.B.; Scuseria, G.E.; Robb, M.A.; Cheeseman, J.R.; Scalmani, G.; Barone, V.; Mennucci, B.; Petersson, G.A.; et al. Gaussian 09, Revision D.01; Gaussian, Inc.: Wallingford, CT, USA, 2013.

66. Chai, J.-D.; Head-Gordon, M. Long-range corrected hybrid density functionals with damped atom-atom dispersion corrections. Phys. Chem. Chem. Phys. 2008, 10, 6615-6620. [CrossRef] [PubMed]

67. Weigend, F.; Ahlrichs, R. Balanced basis sets of split valence, triple zeta valence and quadruple zeta valence quality for $\mathrm{H}$ to Rn: Design and assessment of accuracy. Phys. Chem. Chem. Phys. 2005, 7, 3297-3305. [CrossRef]

68. Cheeseman, J.R.; Trucks, G.W.; Keith, T.A.; Frisch, M.J. A Comparison of Models for Calculating Nuclear Magnetic Resonance Shielding Tensors. J. Chem. Phys. 1996, 104, 5497-5509. [CrossRef]

69. Deng, W.; Cheeseman, J.R.; Frisch, M.J. Calculation of Nuclear Spin-Spin Coupling Constants of Molecules with First and Second Row Atoms in Study of Basis Set Dependence. J. Chem. Theory Comput. 2006, 2, 1028-1037. [CrossRef]

70. Jensen, F. Segmented contracted basis sets optimized for nuclear magnetic shielding. J. Chem. Theory Comput. 2015, 11, 132-138. [CrossRef] [PubMed]

71. Cossi, M.; Barone, V.; Cammi, R.; Tomasi, J. Ab initio study of solvated molecules: A new implementation of the polarizable continuum model. Chem. Phys. Lett. 1996, 255, 327-335. [CrossRef]

72. Tomasi, J.; Mennucci, B.; Cammi, R. Quantum Mechanical Continuum Solvation Models. Chem. Rev. 2005, 105, 2999-3094. [CrossRef]

73. Scalmani, G.; Frisch, M.J. Continuous surface charge polarizable continuum models of solvation. I. General formalism. J. Chem. Phys. 2010, 132, 114110. [CrossRef]

74. Shenderovich, I.G. Experimentally Established Benchmark Calculations of ${ }^{31} \mathrm{P}$ NMR Quantities. Chem. Methods 2021, 1, 61-70. [CrossRef] 
75. Marenich, A.V.; Cramer, C.J.; Truhlar, D.G. Universal solvation model based on solute electron density and on a continuum model of the solvent defined by the bulk dielectric constant and atomic surface tensions. J. Phys. Chem. B 2009, 113, 6378-6396. [CrossRef]

76. Shenderovich, I.G. Simplified Calculation Approaches Designed to Reproduce the Geometry of Hydrogen Bonds in Molecular Complexes in Aprotic Solvents. J. Chem. Phys. 2018, 148, 124313. [CrossRef] [PubMed]

77. Filarowski, A.; Koll, A. Integrated intensity of $\mathrm{OH}$ absorption bands in bent hydrogen bonds in ortho-dialkylaminomethyl phenols. Vibr. Spectrosc. 1996, 12, 15-24. [CrossRef]

78. Pápai, I. Theoretical study of the $\mathrm{Cu}\left(\mathrm{H}_{2} \mathrm{O}\right)$ and $\mathrm{Cu}\left(\mathrm{NH}_{3}\right)$ complexes and their photolysis products. J. Chem. Phys. 1995, 103, 1860-1870. [CrossRef]

79. Borisenko, V.E.; Filarovski, A.I. The electrooptical parameters of aniline and its halogen derivatives in hydrogen bonded complexes. J. Mol. Struct. 1989, 196, 353-370. [CrossRef]

80. Hok, L.; Mavri, J.; Vianello, R. The Effect of Deuteration on the H2 Receptor Histamine Binding Profile: A Computational Insight into Modified Hydrogen Bonding Interactions. Molecules 2020, 25, 6017. [CrossRef] [PubMed]

81. Shenderovich, I.G.; Denisov, G.S. Adduct under Field-A Qualitative Approach to Account for Solvent Effect on Hydrogen Bonding. Molecules 2020, 25, 436. [CrossRef] [PubMed]

82. Dominikowska, J.; Palusiak, M. Tuning Aromaticity of para-Substituted Benzene Derivatives with an External Electric Field. ChemPhysChem 2018, 19, 590-595. [CrossRef] [PubMed]

83. Pylaeva, S.A.; Elgabarty, H.; Sebastiani, D.; Tolstoy, P.M. Symmetry and Dynamics of $\mathrm{FHF}^{-} \mathrm{Anion}_{\text {in }} \mathrm{Vacuum}$ in $\mathrm{CD}_{2} \mathrm{Cl}_{2}$ and in $\mathrm{CCl}_{4}$. Ab Initio MD Study of Fluctuating Solvent-Solute Hydrogen and Halogen Bonds. Phys. Chem. Chem. Phys. 2017, 19, 26107-26120. [CrossRef]

84. Balevicius, V.; Maršalka, A.; Klimavičius, V.; Dagys, L.; Gdaniec, M.; Svoboda, I.; Fuess, H. NMR and XRD study of hydrogen bonding in picolinic acid N-oxide in crystalline state and solutions: Media and temperature effects on potential energy surface. J. Phys. Chem. A 2018, 122, 6894-6902. [CrossRef] [PubMed]

85. Bora, R.P.; Mills, M.J.; Frushicheva, M.P.; Warshel, A. On the challenge of exploring the evolutionary trajectory from phosphotriesterase to arylesterase using computer simulations. J. Phys. Chem. B 2015, 119, 3434-3445. [CrossRef] [PubMed]

86. Shenderovich, I.G.; Limbach, H.-H. Solid State NMR for Nonexperts: An Overview of Simple but General Practical Methods. Solids 2021, 2, 139-154. [CrossRef]

87. Bryce, D.L.; Bernard, G.M.; Gee, M.; Lumsden, M.D.; Eichele, K.; Wasylishen, R.E. Practical Aspects of Modern Routine Solid-State Multinuclear Magnetic Resonance Spectroscopy: One-Dimensional Experiments. Can. J. Anal. Sci. Spectrosc. 2001, 46, 46-82. [CrossRef]

88. Duer, M.J. (Ed.) Solid-State NMR Spectroscopy. Principles and Applications; Blackwell Science Ltd.: Oxford, UK, 2002.

89. Shahi, A.; Arunan, E. Hydrogen bonding, halogen bonding and lithium bonding: An atoms in molecules and natural bond orbital perspective towards conservation of total bond order, inter-and intra-molecular bonding. Phys. Chem. Chem. Phys. 2014, 16, 22935-22952. [CrossRef]

90. Ramabhadran, R.O.; Hua, Y.; Flood, A.H.; Raghavachari, K. C vs N: Which end of the cyanide anion is a better hydrogen bond acceptor? J. Phys. Chem. A 2014, 118, 7418-7423. [CrossRef]

91. Ramabhadran, R.O.; Hua, Y.; Li, Y.J.; Flood, A.H.; Raghavachari, K. From Atomic to Molecular Anions: A Neutral Receptor Captures Cyanide Using Strong C-H Hydrogen Bonds. Chem. Eur. J. 2011, 17, 9123-9129. [CrossRef]

92. Hinchliffe, A. Hydrogen bonding in $\mathrm{HCN} \ldots \mathrm{HF}, \mathrm{HCN} \ldots \mathrm{HCl}, \mathrm{CH}_{3} \mathrm{CN} \ldots \mathrm{HF}$ and $\mathrm{CH}_{3} \mathrm{CN} \ldots \mathrm{HCl}$; an ab initio SCF-MO study. Adv. Mol. Relax. Int. Pr. 1981, 19, 227-237. [CrossRef]

93. Andreeva, D.V.; Ip, B.; Gurinov, A.A.; Tolstoy, P.M.; Denisov, G.S.; Shenderovich, I.G.; Limbach, H.-H. Geometrical Features of Hydrogen Bonded Complexes Involving Sterically Hindered Pyridines. J. Phys. Chem. A 2006, 110, 10872-10879. [CrossRef] [PubMed]

94. Tupikina, E.Y.; Bodensteiner, M.; Tolstoy, P.M.; Denisov, G.S.; Shenderovich, I.G. P=O Moiety as an Ambidextrous Hydrogen Bond Acceptor. J. Phys. Chem. C 2018, 122, 1711-1720. [CrossRef]

95. Arp, F.F.; Bhuvanesh, N.; Blümel, J. Hydrogen peroxide adducts of triarylphosphine oxides. Dalton Trans. 2019, 48, 14312-14325. [CrossRef] [PubMed]

96. Ahn, S.H.; Lindhardt, D.; Bhuvanesh, N.; Blümel, J. Di(hydroperoxy)cycloalkanes Stabilized via Hydrogen Bonding by Phosphine Oxides: Safe and Efficient Baeyer-Villiger Oxidants. ACS Sustainable Chem. Eng. 2018, 6, 6829-6840. [CrossRef]

97. Brotherton, T.K.; Lynn, J.W. The synthesis and chemistry of cyanogen. Chem. Rev. 1959, 59, 841-883. [CrossRef]

98. Provasi, P.F.; Aucar, G.A.; Sanchez, M.; Alkorta, I.; Elguero, J.; Sauer, S.P. Interaction Energies and NMR Indirect Nuclear SpinSpin Coupling Constants in Linear HCN and HNC Complexes. J. Phys. Chem. A 2005, 109, 6555-6564. [CrossRef]

99. Del Bene, J.E.; Alkorta, I.; Elguero, J. Ab initio study of ternary complexes X:(HCNH $)^{+}$: Z with $\mathrm{X}, \mathrm{Z}=\mathrm{NCH}, \mathrm{CNH}, \mathrm{FH}, \mathrm{ClH}$, and FCl: Diminutive cooperative effects on structures, binding energies, and spin-spin coupling constants across hydrogen bonds. J. Phys. Chem. A 2011, 115, 12677-12687. [CrossRef]

100. Sanchez, M.; Provasi, P.F.; Aucar, G.A.; Alkorta, I.; Elguero, J. Theoretical study of HCN and HNC neutral and charged clusters. J. Phys. Chem. B 2005, 109, 18189-18194. [CrossRef] [PubMed]

101. Chan, B.; Del Bene, J.E.; Radom, L. What factors determine whether a proton-bound homodimer has a symmetric or an asymmetric hydrogen bond? Mol. Phys. 2009, 107, 1095-1105. [CrossRef] 
102. Chan, B.; Del Bene, J.E.; Radom, L. Proton-Bound Homodimers: How Are the Binding Energies Related to Proton Affinities? J. Am. Chem. Soc. 2007, 129, 12197-12199. [CrossRef]

103. Shenderovich, I.G. Actual Symmetry of Symmetric Molecular Adducts in the Gas Phase, Solution and in the Solid State. Symmetry 2021, 13, 756. [CrossRef]

104. Kong, S.; Borissova, A.O.; Lesnichin, S.B.; Hartl, M.; Daemen, L.L.; Eckert, J.; Antipin, M.Y.; Shenderovich, I.G. Geometry and Spectral Properties of the Protonated Homodimer of Pyridine in the Liquid and Solid States. A Combined NMR, X-ray Diffraction and Inelastic Neutron Scattering Study. J. Phys. Chem. A 2011, 115, 8041-8048. [CrossRef] [PubMed]

105. Gurinov, A.A.; Lesnichin, S.B.; Limbach, H.-H.; Shenderovich, I.G. How Short is the Strongest Hydrogen Bond in the ProtonBound Homodimers of Pyridine Derivatives? J. Phys. Chem. A 2014, 118, 10804-10812. [CrossRef] [PubMed]

106. Alkorta, I.; Blanco, F.; Elguero, J. A theoretical structural analysis of the factors that affect ${ }^{1} \mathrm{~J}_{\mathrm{NH}},{ }^{1 \mathrm{~h}} \mathrm{~J}_{\mathrm{NH}}{ }^{\text {and }}{ }^{2 \mathrm{~h}} \mathrm{~J}_{\mathrm{NN}}$ in N-H$\cdots \mathrm{N}$ hydrogen-bonded complexes. Mag. Res. Chem. 2009, 47, 249-256. [CrossRef]

107. Krivdin, L.B. Calculation of ${ }^{15}$ N NMR chemical shifts: Recent advances and perspectives. Prog. Nucl. Magn. Reson. Spectrosc. 2017, 102, 98-119. [CrossRef]

108. Benedict, H.; Limbach, H.-H.; Wehlan, M.; Fehlhammer, W.P.; Golubev, N.S.; Janoschek, R. Solid State ${ }^{15}$ N NMR and Theoretical Studies of Primary and Secondary Geometric H/D Isotope Effects on Low-Barrier NHN-Hydrogen Bonds. J. Am. Chem. Soc. 1998, 120, 2939-2950. [CrossRef]

109. Bulychev, V.P.; Buturlimova, M.V.; Tokhadze, K.G. Calculation of interaction of the stretching and bending vibrations of HF in the hydrogen-bonded complex $\left[\mathrm{F}(\mathrm{HF})_{2}\right]^{-}$. Opt. Spectrosc. 2012, 113, 588-592. [CrossRef]

110. Grabowski, S.J. Cooperativity of hydrogen and halogen bond interactions. In Highlights in Theoretical Chemistry, Proceedings of the 8th Congress on Electronic Structure: Principles and Applications (ESPA 2012), Barcelona, Spain, $26-29$ June 2012; Novoa, J., Ruiz López, M., Eds.; Springer: Berlin/Heidelberg, Germany, 2014; Volume 5. [CrossRef] 